07-048

\title{
Do Employment Protections Reduce Productivity? Evidence from U.S. States
}

\author{
David H. Autor \\ William R. Kerr \\ Adriana D. Kugler
}




\title{
Do Employment Protections Reduce Productivity? Evidence from U.S. States*
}

\author{
David H. Autor \\ MIT and NBER
}

\author{
William R. Kerr \\ Harvard Business School
}

Adriana D. Kugler

University of Houston, NBER, CEPR and IZA

January 12,2007

\begin{abstract}
Theory predicts that mandated employment protections may reduce productivity by distorting production choices. Firms facing (non-Coasean) worker dismissal costs will curtail hiring below efficient levels and retain unproductive workers, both of which should affect productivity. These theoretical predictions have rarely been tested. We use the adoption of wrongful-discharge protections by U.S. state courts over the last three decades to evaluate the link between dismissal costs and productivity. Drawing on establishment-level data from the Annual Survey of Manufacturers and the Longitudinal Business Database, our estimates suggest that wrongfuldischarge protections reduce employment flows and firm entry rates. Moreover, analysis of plant-level data provides evidence of capital deepening and a decline in total factor productivity following the introduction of wrongful-discharge protections. This last result is potentially quite important, suggesting that mandated employment protections reduce productive efficiency as theory would suggest. However, our analysis also presents some puzzles including, most significantly, evidence of strong employment growth following adoption of dismissal protections. In light of these puzzles, we read our findings as suggestive but tentative.
\end{abstract}

Keywords: Dismissal Costs, Employment Fluctuations, Entry and Exit, Labor Productivity, TFP, Entrepreneurship.

JEL Classification: J11, J21, J31, J61.

*E-mails: dautor@mit.edu,wkerr@hbs.edu and adkugler@uh.edu. The research in this paper was conducted while the authors were Special Sworn Status researchers of the U.S. Census Bureau at the Boston Census Research Data Center (BRDC). Support for this research from NSF grant (ITR-0427889) is gratefully acknowledged. Research results and conclusions expressed are those of the authors and do not necessarily reflect the views of the Census Bureau. This paper has been screened to insure that no confidential data are revealed. We are grateful to seminar participants at the IZA Conference on Employment Protection and Labor Markets, the Census Bureau RDC Conference, MIT, NBER Labor and Productivity Groups, SOLE, and AEA and, especially, to Daron Acemoglu, Josh Angrist, Giuseppe Bertola, Björn Brügemann, and Paul Oyer for their comments. Autor acknowledges generous support from the National Science Foundation (CAREER SES-0239538) and the Alfred P. Sloan Foundation. Kugler acknowledges support from a GEAR grant from the University of Houston. 


\section{Introduction}

An extensive literature explores the impact of dismissal costs - also frequently called firing costs or employment protection - on the operation of labor markets. Beginning with the seminal work of Lazear (1990), much research has focused on assessing how dismissal costs affect employment levels. Theory suggests, however, that dismissal costs may have ambiguous effects on employment levels. Dismissal costs act as a tax on firing, which reduces dismissals but also reduces hiring. The net effect of these offsetting factors is ambiguous, at least in the short run. It is perhaps not surprising therefore that the empirical literature has found widely varying effects of dismissal costs on employment levels.

By contrast, theory makes a clear prediction about the impact of dismissal costs on the efficiency of hiring and firing. Provided that dismissal protections are not undone by Coasean bargaining, dismissal protections raise firms' adjustments costs. Consequently, firms will find it optimal not to hire workers whose short-term marginal product exceeds their market wage and will choose to retain unproductive workers whose wage exceeds their productivity (cf. Blanchard and Portugal 2001). These distortions in production choices unambiguously reduce worker flows. They are also likely to cause firms to substitute capital for labor and have the potential to reduce productivity by distorting production choices.

This paper evaluates whether, and to what extent, the introduction of dismissal costs affects firms' production choices and, ultimately, their productivity. The source of variation in dismissal costs that we exploit is the adoption of wrongful discharge protections by U.S. state courts from the late 1970s to the early 1990s. These common-law protections against wrongful discharge generated a flood of litigation in adopting states and increased the uncertainty and potential cost of discharging workers. As has been established in prior work using both household survey data and aggregate state-level employment data, adoption of wrongful discharge laws had measurable effects on state employment levels, unemployment-to-employment flows, and the outsourcing of jobs to temporary help employers (cf. Miles 2000; Schanzenbach 2003; Autor 2003; Autor et al. 2004 and 2006; Kugler and Saint Paul 2004). Yet, these aggregate effects have rarely been explored using representative 
microdata on firms, nor have their consequences for productivity been assessed. ${ }^{1}$

In this paper, we simultaneously analyze the consequences of employment protections for establishment-level employment flows and productivity. We first test whether dismissal costs reduce employment volatility — a necessary implication of any standard non-Coasean model—both at the extensive (entry/exit) margin and intensive (within-plant) margin. We next assess whether any reduction in employment volatility is accompanied by a reduction in productivity.

Our analysis exploits detailed, comprehensive establishment-level data from two Census Bureau surveys: the Longitudinal Business Database (LBD) and the Annual Survey of Manufacturers (ASM). Sourced from U.S. tax records and Census surveys, the LBD provides annual employment and payroll information on all U.S. private establishments in most lines of business. The LBD is thus an exceptional resource for identifying the effects of dismissal costs on how firms adjust their labor inputs; its employment and wage records cannot, however, facilitate a further study of the concomitant adjustments of other factors of production and the consequences for productivity. We thus complement the LBD with a balanced panel of 'ongoing' manufacturing plants continuously surveyed by the ASM. We first demonstrate that the impact of dismissal costs on employment adjustment within this panel mirrors the LBD manufacturing universe, and then turn to the ASM's detailed operating data (e.g., output, capital investment, employment) to study extensively the important productivity outcomes.

We find that one of the three dismissal protections adopted during this period, the Covenant of Good Faith and Fair Dealing ('good faith' hereafter), reduced annual employment fluctuations and the entry of new establishments in adopting states. Consistent with the apparent rise in adjustment costs, we document that firms in adopting states engaged in capital deepening, leading to a concurrent rise in labor productivity. Notably, we find evidence of a decline in total factor productivity following adoption of the good faith exception. Our effects are strongest in the short-run, peaking around three years after the adoption and declining afterwards. These results suggest that adop-

\footnotetext{
${ }^{1}$ In contemporaneous work, Bird and Knopf (2005) analyze the effects of wrongful-discharge protections on the earnings, profitability and efficiency of the U.S. banking sector from 1980 to 1990 . They conclude that adoption of wrongful-discharge protections raised wages, reduced profits and lowered productivity in this sector. Petrin and Sivadasan (2006) introduce and implement a novel framework for estimating the effects of employment protection legislation on productivity, focusing on its impact on the gap between workers' marginal revenue product and the wage. Using data from Chile, they find that increases in firing costs raise this gap. Prieger (2005) examines the impact of the Americans with Disabilities Act on the entry and exit of firms in retail.
} 
tion of dismissal protections altered short-run production choices and caused employers to retain unproductive workers, leading to a reduction in technical efficiency. Clouding the interpretation of these results, however, is the finding that adoption of the good faith exception is associated with implausibly large subsequent growth in manufacturing employment. This pattern suggests that our results may be partly contaminated by confounding economic shocks. Thus, while our analysis provides novel direct evidence that employment protections may reduce firm-level productivity, the results must be viewed as tentative. It is our hope that future studies will provide further exploration of these initial results.

\section{Wrongful Discharge Protections in the United States}

The U.S. has long had a legal presumption that workers and employers may freely terminate their employment relationships 'at will,' that is without notification, financial penalty or requirement to demonstrate good (or any) cause. This legal doctrine, referred to as employment-at-will, was first articulated by the Tennessee Supreme Court in 1884 and was subsequently adopted into the common law by almost all U.S. state courts by the mid 1930s (cf. Morriss 1994). ${ }^{2}$

Beginning in the 1970s, the legal consensus supporting employment-at-will eroded rapidly. In a series of precedent-setting cases between 1972 and 1992, the vast majority of U.S. state courts adopted one or more common-law exceptions to the employment-at-will doctrine. These exceptions constrained the ability of employers operating in adopting states to terminate workers 'at will.' These common-law exceptions are typically classified into three categories: 1) the implied covenant of good faith and fair dealing ('good faith' exception); 2) the tort of wrongful discharge in violation of public policy ('public policy' exception); and 3) the implied-in-fact contract not to terminate without good cause ('implied contract' exception). ${ }^{3}$ We summarize these exceptions here and refer

\footnotetext{
${ }^{2}$ Idaho, New Jersey and New Mexico adopted employment-at-will in 1948, 1953 and 1968, respectively. Prior to Idaho, the most recent was Wyoming in 1937. Montana is the only state to have implemented exceptions to the employment-at-will doctrine by statute rather than common law (cf. Ewing et al. 2005).

${ }^{3}$ For detailed discussion of the evolution of the employment-at-will doctrine, see Morriss (1994 and 1995), Autor (2003), Kugler and Saint Paul (2004) and Autor et al. (2006). Our discussion draws particularly on the latter work, which contains (at present) the most current legal analysis. Legal scholars, including most notably Dertouzos and Karoly (1992), also categorize these exceptions according to whether they allow for tortious damages (i.e., pain, suffering, and possibly punitive damages) in addition to contractual damages (i.e., exclusively economic losses). Recent work has not found that this distinction is empirically relevant (cf. Autor et al. 2006), however, and hence we focus on the three categories of legal exception.
} 
the reader to Autor et al. (2006) for an extended discussion.

Read broadly, the good faith exception prohibits employers from firing workers for 'bad cause.' The definition of 'bad cause,' however, varies greatly by state and over time. The California Court of Appeals' famous 1980 good faith ruling in Cleary v. American Airlines ${ }^{4}$-likely the most influential of all good faith cases - was initially understood to bar California employers from terminating any worker without good cause. However, the California Supreme Court's 1988 ruling in Foley v. Interactive Data Corp vastly reduced the scope of the Cleary decision and limited the financial remedies available to plaintiffs. ${ }^{5}$ At present, all eleven state courts that recognize the good faith exception (including California) primarily limit awards to 'timing' cases in which the employer intentionally terminates a worker to deprive her of a promised benefit (e.g., a sales commission or non-vested pension). Hence, 'bad cause' under the good faith exception is currently construed narrowly, though this was not always the case.

The public policy exception, recognized by 43 states as of 1999, provides workers with protections against discharges that would inhibit them from acting in accordance with public policy. In states recognizing the public policy exception, workers may, for example, litigate if they are fired for performing jury duty, filing a worker's compensation claim, reporting an employer's wrongdoing, or refusing to commit perjury on behalf of the employer. Because courts typically limit public policy cases to clear violations of explicit legislative commands, rather than violations of a vaguer sense of public obligation, the public policy exception is not generally thought to impose substantial constraints on employer behavior.

The implied contract exception, also recognized by 43 states in 1999, comes into force when an employer implicitly promises not to terminate a worker without good cause. Such implicit promises may include, for example: personnel manuals stating that the employer's policy is to terminate employees only for just cause; expectations arising from a worker's longevity of service or history of promotions and salary increases; and usual company practices that preclude terminating workers without good cause. The expected economic impact of the implied contract exception

\footnotetext{
${ }^{4} 168$ Cal. Rptr. 722 (Cal. Ct. App. 1980 October).

${ }^{5} 765$ P.2d 373 (Cal. 1988). Whereas the Cleary decision permitted plaintiffs to recover tortious damages for violations of the good faith doctrine, Foley reduced these damages to contractual losses (cf. Jung and Harkness 1989).
} 
is hard to gauge. On the one hand, employers can potentially 'contract around' this exception simply by rewording personnel manuals and adding explicit language to employment contracts to state that all employees remain 'at will.' ${ }^{6}$ On the other hand, firms without sophisticated human resources staff may be unaware of the implied contract exception or lack the expertise to fully insulate themselves from its reach. Additionally, the implied contract exception can potentially reclassify an employer's entire workforce as not 'at will,' which may impose significant costs.

To assess the effects of these employment-at-will exceptions on productivity and employment outcomes, we adopt a difference-in-difference approach that contrasts state-level change in outcomes in adopting states to contemporaneous changes in outcomes in non-adopting states. This treatment-control contrast identifies the average causal effect of the exceptions on the outcomes of interest under the assumption that these outcomes would have otherwise evolved similarly in adopting and non-adopting states. We take a number of steps to buttress the robustness of this statistical approach. All econometric models include industry or industry-by-year fixed effects (in addition to state fixed effects) to absorb industry-wide shocks that may be correlated across states. In addition, most specifications include state-specific linear time trends to account for possible pre-existing trends that may predate the adoption of employment-at-will exceptions and could otherwise be confounded with adoption. Some specifications further include plant fixed effects, where identification comes from contrasts of within-plant changes in outcomes in adopting relative to non-adopting states. As a falsification test, we also estimate dynamic models that contrast changes in outcomes in years prior to and following adoption of exceptions to provide a check on the possibility that adoption of employment-at-will exceptions are caused by changes in outcomes rather than vice-versa.

Figure 1 plots the number of states recognizing each of the three exceptions during the time period of 1970 to 1999 (at monthly frequency). ${ }^{7}$ Two main points are visible. First, the public policy and implied contract exceptions are far more widely recognized than the good faith exception.

\footnotetext{
${ }^{6}$ And indeed, large employers took such steps. The Bureau of National Affairs (1985) found that 63 percent of large employers surveyed in the early 1980s had recently "removed or changed wording in company publications to avoid any suggestion of an employment contract," and 53 percent had "added wording to applications and handbooks specifying that employment may be terminated for any reason." Sutton and Dobbin (1996) report that the percentage of firms using 'at will' clauses in employment contracts increased from 0 to 29 percent between 1955 and 1985.

${ }^{7}$ The dips in the series reflect court reversals of doctrines that were previously recognized.
} 
Second, adoption of each exception appears to follow something of a contagion pattern, with a large number of adoptions occurring in rapid succession between 1976 and 1988, followed by nearstasis from 1988 forward. This pattern suggests that adoptions that cannot be viewed as fully independent, but that a widespread change in legal thinking in the 1970s and 1980s led many state courts to amend the longstanding doctrine of employment-at-will at around the same time. This potentially presents a challenge for identification in that businesses might react in advance to anticipated changes in the legal environment, thus blurring the pre-post contrast. However, the date at which a state adopts a given exception is an idiosyncratic function of the cases brought before state high courts and the disposition of the sitting judges. Many states never adopt exceptions and others reverse or amend these exceptions after adoption. Accordingly, precedent-setting cases that generate exceptions to employment-at-will typically will provide a discrete element of surprise. This is particularly likely to be true for the good faith exception, which was adopted more slowly and less extensively than either the public policy or implied contract exceptions.

As emphasized by Autor et al. (2006), it is likely that a substantial component of the economic cost of the employment-at-will exceptions emanates from the uncertainty they introduced into the employment relationship. When most exceptions were adopted in the late 1970s through late 1980s, the volume and cost of wrongful discharge litigation that would ultimately ensue was unknown to firms and potential litigants. Adding to the uncertainty, personnel and professional law journals (i.e., the trade publications relied upon by personnel managers and corporate attorneys) published numerous articles that appeared to overstate the scope of the protections afforded to workers and the penalties that firms would incur for violating them (cf. Edelman et al. 1992). Because employers were potentially led to anticipate greater constraints and costs than ultimately materialized, Autor et al. (2006) argue that the short-term and medium-term effects of these dismissal protections may have exceeded their 'steady-state' effects, and they present evidence consistent with this hypothesis.

Several prior studies have analyzed the effects of employment-at-will exceptions on labor market outcomes. The first study in this vein, Dertouzos and Karoly (1992), found using aggregate statelevel data that adoption of common-law dismissal protections reduced state employment levels by as much as seven percent. Subsequent analyses by Miles (2000), Schanzenbach (2003) and Autor et al. (2004 and 2006) using industry-level and household-level data do not confirm these results, 
however. These more recent studies find either modest negative effects (Autor et al., Schanzenbach) or no effects of dismissal protections on employment levels (Miles). As noted above, however, theory makes ambiguous predictions about the impact of dismissal costs on employment levels.

A number of studies also provide evidence that states' adoption of dismissal protections raised hiring and firing costs. Miles (2000) and Autor (2003) show that employers in adopting states substituted temporary help agency workers for direct-hire employees, presumably in an effort to minimize litigation risks. ${ }^{8}$ Kugler and Saint-Paul (2004) find using the National Longitudinal Survey of Youth that these protections (especially the good faith exception) reduced the re-employment probability of unemployed relative to employed workers, suggesting that dismissal protections exacerbated adverse selection into non-employment. Both sets of findings are significant for our work because they demonstrate that the adoption of dismissal protections raised firms' adjustment costs - a necessary condition for them to have had productivity impacts.

Our study builds on this prior work in two major respects. First, use of establishment-level data provides direct evidence on the effects of dismissal protections on firms' employment adjustments at both the extensive (plant opening/closing) and intensive (job flows) margins. Second, we directly evaluate the consequences of dismissal protections for establishment-level production choices and realized productivity.

\section{Theoretical Considerations}

In a standard competitive model of the labor market, employment protections are economically equivalent to mandated employment benefits. Benefit mandates raise the cost of employing workers, leading to an inward shift in labor demand. If, however, workers value the mandated benefit at its marginal cost of provision - that is, the mandate is efficient - then the Coase theorem applies. Labor supply shifts outward to offset the inward shift in labor demand, employment levels are unchanged and wages fall to cover exactly the cost of the benefit (cf. Summers 1989; Lazear 1990). There are no productivity or employment consequences. ${ }^{9}$

\footnotetext{
${ }^{8}$ The implied contract exception in particular confers a comparative advantage on temporary help agencies since these firms are universally understood to offer only short-term employment. It is the implied contract exception that appears primarily responsible for the growth of temporary help agency employment (cf. Autor 2003).

${ }^{9}$ Aghion and Hermalin (1990) and Levine (1991) present models in which dismissal protections are under-provided by the private market due to adverse selection. Bertola (2004) also presents a model in which dismissal costs are under-
} 
Mandatory dismissal protections can impose efficiency costs in the competitive model, however. If workers value dismissal protections at less than their marginal cost of provision — or, equivalently, if some share of the termination benefit accrues to a third-party, such as an attorney-the benefit mandate drives a wedge between the private and social cost of job separations, yielding a deadweight loss. Because dismissal costs are only paid when workers and firms separate, the deadweight loss component of the dismissal cost functions as a tax on separations - an adjustment cost. Consider, for example, a case where a worker's marginal product falls below his wage and the wage cannot drop sufficiently to compensate the firm (either due to a non-negativity constraint or due to downward wage rigidities). If the worker values the dismissal benefit at its marginal cost, both the worker and the firm will agree to terminate the job. If the payment of the dismissal benefit incurs a deadweight loss, however, both the worker and the firm will find it optimal to continue the employment relationship so long as the present value of the productivity shortfall is less than the deadweight loss. Consequently, inefficient dismissal protections - that is, protections that workers value at less than cost - inhibit efficient job separations (and, indirectly, reduce efficient accessions as well).

In the competitive model, these inefficient dismissal protections unambiguously reduce allocative efficiency - that is, they are welfare reducing. Their implications for the technical efficiency of production are less clear cut. If dismissal protections cause firms to retain (some) unproductive workers, this will cause a decline in labor productivity, ceteris paribus. Offsetting this factor, firms may screen new hires more stringently, leading to a favorable compositional shift in the productivity of the employed workforce. Moreover, because inefficient dismissal protections provide firms with an incentive to substitute from labor to other factors of production, capital deepening may also raise the marginal product of labor. Hence, the net impact on technical efficiency (as opposed to allocative efficiency) is ambiguous.

While many labor economists use this competitive model as a benchmark, much of the macro-

provided due to risk-aversion. Agell (1999) discusses why eliminating dismissal protections may not be desirable when labor markets are subject to fairness considerations and market imperfections, while Wasmer (2006) and Macleod and Nakavachara (2006) focus on human capital investment. In all these cases, dismissal protection mandates can be efficiency-enhancing since workers may value these protections above their cost of provision. In the Coasean model, this would imply that imposing the mandate would raise employment levels. See Saint-Paul (2002) and Brügemann (2006) for theories on the political economy of employment protection. 
economic literature views employment protection through the lens of the Diamond-MortensenPissarides equilibrium unemployment model (cf. Mortensen and Pissarides 1994; Kugler et al. 2003). As in the competitive model, dismissal costs in the equilibrium unemployment model curtail efficient separations by reducing the threshold productivity at which firms are willing to dismiss workers, thus reducing productivity. In contrast to the competitive model, however, worker-firm matches in the equilibrium unemployment setting generate quasi-rents, and the allocation of rents between firms and workers is typically determined through Nash bargaining. Nash bargaining exacerbates the deadweight loss from inefficient employment protections. ${ }^{10}$ In the Nash bargain, dismissal costs reduce the firms' outside options or 'threat points,' causing workers' wage demands to rise even as profits fall. Facing lower profits and higher wage demands, firms curtail job creation and increase the threshold productivity at which they are willing to hire. The induced rise in reservation productivity potentially leads to an increase in firm-level productivity since less productive matches are not realized. ${ }^{11}$ Hence, the net productivity effect is again ambiguous.

Although the competitive and equilibrium unemployment models differ in their details, both imply that dismissal protections dampen employment adjustments but have ambiguous effects on firms' productivity. On the other hand, both models indicate that if dismissal protections do not reduce job flows (perhaps because they satisfy Coasean equivalence), these protections should not affect productivity. These theoretical observations motivate our empirical approach. We begin by assessing whether adoptions of exceptions to the employment-at-will doctrine reduce job flows. We next turn to an analysis of their consequences for firm productivity. Because of the many possible avenues of adjustment noted above, our empirical work examines the impacts of dismissal protections on multiple plant-level production outcomes including capital investment, capital intensity, labor productivity and total factor productivity.

\footnotetext{
${ }^{10}$ Nash bargaining amplifies inefficiencies because it is non-Coasean; the initial allocation of property rights affects both the distribution of resources and the efficiency of bargained outcomes (cf. Grout 1984).

${ }^{11}$ Although productivity impacts are ambiguous, welfare consequences are generally negative, as in the competitive case above. If the search equilibrium is not initially constrained efficient, however, it is possible for policy interventions to improve aggregate efficiency (cf. Pissarides 2000, chapter 8).
} 


\section{Data Description}

Establishment-level data are essential for characterizing how firms and their associated establishments respond to the passage of dismissal protections. This project draws such data from two confidential surveys collected by the Census Bureau - the Longitudinal Business Database (LBD) and the Annual Survey of Manufacturers (ASM). Each survey is described below, and Table 1 provides descriptive statistics.

\subsection{Longitudinal Business Database}

The LBD is a unique source for studying employment dynamics across manufacturing and nonmanufacturing sectors. Sourced from IRS tax data and Census surveys, the LBD annually covers approximately 3.9 million establishments with positive employment, representing over 68 million employees, in most U.S. private industries. Panel A of Table 1 highlights that most of the LBD's surveyed employees are in the manufacturing, retail trade and services sectors. These percentages are fairly similar for states passing dismissal protections and those not doing so. ${ }^{12}$

The microdata first facilitate the development of complete state-industry-year panels of employment by summing employment counts across individual establishments. Publicly available series normally do not provide employment counts by state-industry; even when they do so, the Census Bureau is required to suppress values that compromise the confidentiality of individual establishments. Building from the microdata overcomes these limitations and a full employment panel is developed for the 1976 to 1999 sample frame.

From this state-industry-year panel, we can estimate absolute year-over-year employment changes. The mean absolute employment change over the sample is approximately 11 percent. This absolute job turnover metric aggregates over employment adjustments on the intensive margin (i.e., the hiring and firing of workers by continuing establishments) and the entry/exit margin. In the LBD, establishments are assigned unique and time-invariant identifiers that further afford longitudinal estimations of these two dimensions of adjustment. The entry and exit rates for establishments are

\footnotetext{
${ }^{12}$ The LBD's sample frame during the 1976 to 1999 period includes mining; construction; manufacturing; wholesale trade; retail trade; and services (except hospitals, education services, social services, and private households). Sectors not included for the full panel are agriculture, forestry and fishing; transportation and public utilities; finance, insurance and real estate; and public administration. Jarmin and Miranda (2002) describe the construction of the LBD.
} 
approximately 13 percent and 11 percent, respectively. As many entering and exiting establishments are very small in size, only 7 percent and 6 percent of employees are working in entering or exiting establishments, respectively. ${ }^{13}$ Finally, the survey's reporting structure affords the linkage of establishments to their parent firms. Approximately 22 percent of establishments and 55 percent of employees are part of multi-unit firms.

\subsection{Annual Survey of Manufacturers}

While the LBD provides a comprehensive view of employment dynamics across manufacturing and non-manufacturing sectors, reported data are limited to total employment and payroll only. To evaluate the impact of reduced job turnover for capital and productivity outcomes, we turn to two detailed surveys of manufacturers undertaken by the Census Bureau. The Census of Manufacturers (CM) collects operating data on all U.S. manufacturing plants at five-year intervals (i.e., 1972, 1977, and so on). In between the CMs, the Census Bureau conducts the Annual Survey of Manufacturers (ASM). The ASM is a probability sampled subset of the CM, with the panel redrawn two years after each CM. Plants with more than 250 employees in the previous CM are sampled with certainty.

We extract from the ASM a balanced panel of all plants continuously monitored from 1972 to 1999. This restriction focuses on intensive adjustments in large plants operating in stable business climates; by conditioning on survival, the extensive margin is suppressed. While the approximately 5700 plants represent less than 2 percent of all U.S. manufacturing establishments, they account for over a quarter of total manufacturing activity in terms of employments and shipments. Almost all of these plants are part of multi-unit firms, although not all of the plants have sister establishments within this balanced panel.

Year-over-year employment changes are again studied. While the average annual employment change is again 11 percent, a larger fraction of these changes are negative, reflecting the trend decline in manufacturing employment from 1976 to 1999. In addition, the more detailed employment data for manufacturers allow us to examine production and non-production workers separately; the mean non-production worker employment share is 26 percent.

The continuous monitoring of this ASM panel affords the calculation of detailed capital stocks

\footnotetext{
${ }^{13}$ Dunne et al. (1989) and Kerr and Nanda (2006) provide additional descriptive statistics on entry and exit patterns in the manufacturing and non-manufacturing sectors, respectively.
} 
and productivity metrics. Capital stocks are calculated with the perpetual inventory method, as explained below. The mean plant-level capital stock for the 1976 to 1999 sample is $\$ 31 \mathrm{~m}$ in 1999 dollars. Labor productivity is defined as deflated total value of shipments divided by total plant employment. Finally, we estimate total factor productivity (TFP) as the residual from a production function of value-added on four factors: production workers, non-production workers, machinery capital, and structures capital.

\section{Consequences of Employment Protections}

In this section we discuss the impact of wrongful discharge protections on firm behavior. We begin by examining the first-order effect of employment protections on employment fluctuations, both at the intensive (within-establishment) and extensive (entry/exit) margins. If wrongful discharge protections increase adjustment costs, this should lead to a reduction in hiring and dismissals, resulting in an overall dampening of employment fluctuations. We next test the impact of employment protections on employment levels, a margin along which prior research has obtained mixed results. Finally, we turn to the important question of whether the possibly restricted ability of businesses to adjust employment due to the introduction of employment protections has productivity consequences.

\subsection{Effects on Employment Fluctuations}

We estimate the effects of the wrongful discharge exceptions (i.e., good faith, public policy and implied contract) described in Section (2) on employment fluctuations using both the LBD and ASM. We begin by estimating the following equation using the LBD:

$$
A B S_{s j t}=\lambda_{s}+\kappa_{j}+\tau_{t}+\beta_{G F} G F_{s t-1}+\beta_{P P} P P_{s t-1}+\beta_{I C} I C_{s t-1}+\varepsilon_{s j t},
$$

where $A B S_{s j t}$ is the absolute year-to-year employment change of a two-digit SIC sector $j$, in state $s$, at time $t$,

$$
A B S_{s j t}=\frac{\left|E_{s j t}-E_{s j t-1}\right|}{\left[\frac{\left(E_{s j t}+E_{s j t-1}\right)}{2}\right]} .
$$


$\lambda_{s}, \kappa_{j}$ and $\tau_{t}$ are vectors of state, industry and time effects, respectively. ${ }^{14} G F_{s t-1}, P P_{s t-1}$ and $I C_{s t-1}$ are indicators of whether the good faith, public policy and implied contract exceptions were in place in state $s$ at time $t-1 .{ }^{15}$ Thus, the coefficients $\beta_{G F}, \beta_{P P}$ and $\beta_{I C}$ capture the effects of employment protections on annual net employment flows. ${ }^{16}$

Our core battery of specifications also includes two estimations of greater stringency. First, we consider models with state-specific time trends. These require that identification come from the discontinuity surrounding the passage of the wrongful discharge exception. These specifications can provide reassurance that our coefficients are not reflecting smoothly trending omitted variables that are potentially correlated with the adoption of the exceptions. A benefit of the state-industry panel is that we can also control for industry-specific trends using the non-parametric form of two-digit SIC industry and year interactions. These latter estimations allow us to control for employment shifts due to national trends in a state's industries, again providing confidence in the identification strategy.

Panels A and B of Table 2 report estimates of the effects of the wrongful discharge exceptions on employment fluctuations for the Full Sample and for manufacturing only. Panel A includes all LBD sectors: manufacturing, mining, construction, wholesale trade, retail trade and services. The reported standard errors account for possible error correlations across firms within a state and within states over time. We weight the samples using the mean employment level in the stateindustry-year cells during the early 1976 to 1985 period. The results for the Full Sample show a decline in employment fluctuations following the introduction of the good faith exception, though the results are not statistically significant. By contrast, the results for the public policy and implied contract exceptions show insignificant positive impacts on employment fluctuations.

When we estimate these models for manufacturing alone in Panel $\mathrm{B}$, we find a negative, and in the majority of cases, significant, effect of the good faith exception on employment fluctuations.

\footnotetext{
${ }^{14} A B S$ is closely linked to Davis et al. (1996)'s job reallocation measure estimated at the sector level, which adds the average positive changes in employment in a sector to the average negative changes in employment in a sector. $A B S$ is defined to be zero if both employments are zero. $A B S$ is bounded between $[0,2]$, thereby minimizing the influence of outliers.

${ }^{15}$ The one-year lag from the survey date is due to employment counts in the LBD and ASM usually being measured as of March 1st.

${ }^{16}$ In addition to the $A B S$ measure, we estimated models that distinguish between positive and negative adjustments. Since we were unable to reject the hypothesis that the results are symmetric on both margins, we suppress tabulation of these results.
} 
This result is robust to the inclusion of state-specific and industry-specific trends. It suggests a reduction in employment fluctuations of 5 to 12 percent after the introduction of the good faith exception (i.e., dividing the -0.006 to -0.016 coefficients by the average annual employment change of $13 \%$ in Table 1 for states adopting the good faith exception). The results for the implied contract exception remains insignificant. Surprisingly, we find a positive and significant impact of the public policy doctrine on employment fluctuations in the LBD data. This latter result, however, is not supported in the upcoming analysis of the more accurate, establishment-level ASM panel.

The initial LBD analysis suggests a significant effect of the good faith exception on employment fluctuations in manufacturing. To test whether this finding is consistent with a causal relationship, we evaluate the relationship between the adoption of the good faith exception and employment fluctuations using a dynamic specification:

$$
\begin{aligned}
A B S_{s j t}= & \lambda_{s}+\kappa_{j}+\tau_{t}+\sum_{q=-5}^{2} \beta_{G F t+q} \Delta G F_{s t+q}+\sum_{q=-5}^{2} \beta_{P P t+q} \Delta P P_{s t+q}+\sum_{q=-5}^{2} \beta_{I C t+q} \Delta I C_{s t+q} \\
& +\beta_{G F t-6} G F_{s t-6}+\beta_{P P t-6} P P_{s t-6}+\beta_{I C t-6} I C_{s t-6}+\varepsilon_{s j t}
\end{aligned}
$$

where $\Delta G F_{s t+q}, \Delta P P_{s t+q}$ and $\Delta I C_{s t+q}$ indicate whether adoption occurred at year $t+q$. These dynamic variables capture the transitory effects of the reforms. $G F_{s t-6}, P P_{s t-6}$ and $I C_{s t-6}$ estimate long-term outcomes by indicating adoptions that occurred at year $t-6$ or before. These coefficients are relative to the period three years prior to the reform, and their pattern indicates whether the earlier pre-post results (1) are consistent with a causal interpretation. In particular, we would be concerned if there are large and statistically significant coefficients on the lead indicators, regardless of whether they are positive or negative. The specification also helps identify whether the largest impacts of the exceptions occur over the short-run or long-run. ${ }^{17}$

Appendix Table 1 presents results from this dynamic specification estimated for the manufacturing sector, as well as additional specifications including state-specific and industry-specific trends. The basic specification shows negative coefficients for the good faith lags, but mostly insignificant and weakly positive coefficients for the leads, thus supporting a causal interpretation of our results. That is, the introduction of the exception precedes employment changes and not vice

\footnotetext{
${ }^{17}$ The dynamic estimations also include a second set of lead and lag variables to account for the four cases in which legal exceptions were formally abandoned. The inclusion or exclusion of these additional regressors does not materially influence the reported results.
} 
versa. By contrast, the public policy and implied contract leads and lags have typically positive coefficients. The pattern for the public policy doctrine is particularly noteworthy since it suggests that the unexpected positive estimate for the impact of this doctrine on employment fluctuations found in Table 2 is likely to be spurious. These patterns are robust to the inclusion of state-specific and industry-specific trends. The results using the LBD suggest that the impact of the good faith doctrine peaks approximately three years following adoption and that the long-term effect is insignificant (i.e., six or more years following adoption). This pattern is comparable to Autor et al. (2006), who report that the near-term effects of adoption of wrongful discharge doctrines dissipate within approximately five years, perhaps because the initial market uncertainty about the potentially vast - but ultimately modest scope - of the protections offered is resolved (cf. Edelman et al. 1992). ${ }^{18}$

Table 2's results from the LBD suggest that manufacturing was particularly affected by the introduction of wrongful discharge exceptions, likely because manufacturing employment is highly seasonal and highly cyclical, making dismissal protections particularly costly. ${ }^{19}$ We use plant-level data from the ASM to further examine the effects of employment protections in manufacturing. Panel A of Table 3 presents analogous results to those using the LBD in Table 2. Because our ASM sample uses a balanced panel of ongoing plants, we can now add plant fixed effects to the prior specification, leading to the following estimating equation:

$$
A B S_{p t}=\mu_{p}+\tau_{t}+\beta_{G F} G F_{s t-1}+\beta_{P P} P P_{s t-1}+\beta_{I C} I C_{s t-1}+\varepsilon_{p t} .
$$

The dependent variable is the absolute year-to-year employment change in plant $p$ from $t-1$ to $t ; \mu_{p}$ is a plant fixed effect. As before, we include state-specific and industry-specific trends. The estimated standard errors again allow for error correlations across plants within states and within states over time. ${ }^{20}$

\footnotetext{
${ }^{18}$ Only 13 states introduced good faith exceptions during the period studied. California introduced the first good faith exception in a highly visible court ruling. Though our basic and dynamic LBD results on employment changes are strongest for the full sample of states, the results are qualitatively similar but less precise when California is excluded.

${ }^{19}$ The mean year-to-year turnover in manufacturing was $12 \%$, compared to $10 \%$ in construction, $6 \%$ in wholesale trade, $7 \%$ in retail trade, and $8 \%$ in services. Only mining had a higher annual turnover $(27 \%)$. Regressions examining the mining sector also find a substantial dampening of annual employment volatility following the adoption of the good faith exception.

${ }^{20}$ We have also estimated analogous models using an unbalanced panel of ASM plants (i.e., not limited to those
} 
Consistent with the LBD, the results using the ASM suggest that the good faith exception reduces employment fluctuations. We do not find evidence, however, in the ASM sample that the implied contract or public policy doctrines impact employment fluctuations. We estimate in Table $3 \mathrm{~A}$ that the good faith exception reduces employment fluctuations by 1.5 to 4.5 percent, which is about half the size of the estimate using the LBD data. While this finding is only marginally statistically significant, supporting evidence from dynamic specifications below suggest that the effect is likely to be causal.

The difference between the LBD and ASM results are explained in part by the fact that in the ASM we can control for additional unobservable factors affecting a plant's employment fluctuations. Contrasting Columns (4) and (6), with and without plant fixed effects, we can see that excluding plant effects using our ASM sample implies a reduction of 5 percent in employment fluctuations as opposed to 2 percent with plant effects. As is shown in the next sections, the remaining differences between the estimates in the LBD and the ASM samples are likely due to the fact that the LBD includes entering and exiting business while the ASM sample is composed of a balanced sample of ongoing plants. The ASM analysis therefore excludes any effect of wrongful discharge protections on employment fluctuations occurring through entry and exit.

As with the LBD, we also estimate a dynamic specification using ASM data. Table 3B presents these estimates. Similar to the patterns found with the LBD, leads of the good faith exception are found to have weakly positive and insignificant effects on employment fluctuations while lags of the good faith exception have negative effects on employment changes. The maximum dampening is again attained three years following adoption. As with the LBD estimates, the long-term impacts are insignificant and, in the case of the ASM, weakly positive. ${ }^{21}$

Since employment protections may also affect seasonal employment fluctuations (cf. Wolfers 2005), we also study a quarterly employment churn measure to complement the year-over-year changes. In particular, we estimate equation (3) using as a dependent variable the following measure continually operating). Findings from these models, which are qualitatively similar, are available from the authors on request.

${ }^{21}$ As for the LBD results, the ASM findings are qualitatively similar but somewhat less precise when we exclude California from our sample. As a complement to the panel estimations, similar results are found with lagged dependent variable specifications that test for mean reversion. 
of quarterly churn for production workers: ${ }^{22}$

$$
\text { PWChurn }_{p t}=\frac{P W_{p t}^{\max }-P W_{p t}^{\min }}{\left[\frac{\left(P W_{p t}^{\max }+P W_{p t}^{\min }\right)}{2}\right]},
$$

where $P W_{p t}^{\max }$ and $P W_{p t}^{\min }$ are the maximum and the minimum quarterly production-worker employment in plant $p$ in year $t$, respectively. As before we allow for state-specific and industry-specific trends and cluster the standard errors on state.

Panel B of Table 3A shows results for these specifications. Estimates without state trends show negative effects of the good faith exception on seasonal adjustments of production workers, but the results are not significant and the effects become positive when controlling for state trends. Looking deeper, however, the results from the underlying dynamic specifications reported in Table 3C consistently show weakly positive coefficients on the leads and negative coefficients on the lags. Moreover, the dampening is again most significant three years after the adoption. Thus, the dynamic specifications appear most consistent with a significant causal effect of the good faith exception on seasonal employment fluctuations over the short-run to medium-run.

\subsection{Effects on Entry and Exit}

The difference in the magnitudes of the estimated effects of wrongful discharge exceptions on employment fluctuations in the LBD and the ASM samples suggests that part of the reduction in employment fluctuations observed following adoption of the good faith exception is explained by changes in firm entry and exit (i.e., the extensive employment margin). To evaluate the importance of external adjustment, we use the LBD to estimate regressions similar to equation (1), where the dependent variable is the log of the average count of plants over five-year intervals among continuing, entering and exiting businesses. We use five-year averages to minimize the possibility of capturing spurious entry and exit due to 'ghosting' and reporting bumps observed surrounding Census years. The wrongful discharge indicators take the value of one if the exceptions had been adopted as of the midpoint of the five-year intervals. ${ }^{23}$

\footnotetext{
${ }^{22}$ The ASM does not collect quarterly employment for non-production workers. The plant-level ASM does not allow us to separately estimate employment effects by demographic group, as is feasible with data from household surveys as in Kahn (2006).

${ }^{23}$ Annual regressions of entry and exit yield quantitatively similar results, though the magnitudes are smaller. Studying entry and exit at five-year intervals avoids spurious peaks of entry and exit rates surrounding Census years,
} 
Panels A through D of Table 4 report results of these regressions for total, continuing, entering and exiting plants, respectively. Panel A shows little change in the total count of plants in response to the introduction of any of the exceptions. However, Panels B through D show that in the case of the good faith exception, this reflects countervailing forces among continuing and other plants. Panel B shows an increase in plant survival after the introduction of good faith exceptions, though this effect is only marginally significant. Panel $\mathrm{C}$ shows that entry is substantially reduced in manufacturing after the introduction of good faith exceptions, though exit is unaffected. These results, controlling for state-specific and industry-specific trends, suggest a reduction of 7.7 log points in the number of entering plants, where log points refer to 100 times the coefficient in the log-linear specification (thus roughly corresponding to percentage point changes). ${ }^{24}$ This translates into a reduction of about 9,000 establishments. By contrast, the public policy and implied contract exceptions do not appear to affect entry.

In combination with the findings in Tables 2 and 3, these results suggest that the dampening effect of the good faith exception on employment fluctuations operates through two channels: a reduction in net employment flows in ongoing plants and a reduction in the entry of new plants. The reduced rate of establishment creation helps reconcile the smaller decline in employment fluctuations evident in the ASM panel compared to the LBD. ${ }^{25}$

\subsection{Effects on Employment Levels}

Here we explore the effects of wrongful discharge exceptions on employment levels. As discussed, the effect of these dismissal protections on net employment is theoretically ambiguous (at least in the short run) since both dismissals and hiring are affected.

We start by estimating similar regressions to equation (3) using the ASM data, but where the dependent variable is the log of employment in plant $p$ at time $t$. Table 5 presents results of

when additional manpower is devoted to updating the business registry. This updating has a noticeable effect on establishment counts, but not on summed employment levels used for year-to-year employment changes. Entry and exit are defined as the first and last year an establishment is observed in the LBD, respectively, with the end years of the sample excluded. Establishments alive for a single year are recorded as both entering and exiting. This procedure ignores potential exit and re-entry by establishments, but more importantly avoids spurious entry and exit from 'ghosting' establishments with poor longitudinal linkages.

${ }^{24}$ This result is consistent with Kugler and Pica (forthcoming), who find that increased dismissal costs in Italy after the 1990 labor market reform reduced entry of small firms.

${ }^{25}$ See Koeniger and Prat (2006) for analysis of product market regulation and the extensive margin. 
these regressions for total employment as well as for production and non-production employment separately. Panel A shows that total employment increases with the introduction of the good faith and public policy exceptions, though the public policy results are insignificant. The implied contract exception has a negative though insignificant effect on employment, which is consistent in sign and magnitude - though not statistical significance - with the findings in Autor et al. (2004 and 2006).

When employment is disaggregated into production and non-production workers, we find that the increase in total employment following the introduction of the good faith exception is driven primarily by the increase in employment of non-production workers. For example, the final columns of Panels $\mathrm{B}$ and $\mathrm{C}$ suggest that production employment does not react to the introduction of the good faith exception while non-production employment in the typical plant increases by 4.8 log points following the introduction of this exception. ${ }^{26}$ This differential rise in non-production demand may be explained by capital-skill complementarity (cf. Griliches 1969; Berman et al. 1994), as Section (5.4) will show that the adoption of the good faith exception may have spurred capital-deepening in firms.

As before we also estimate dynamic specifications to test whether our findings are consistent with a causal interpretation. In these specifications, found in Appendix Table 2, the estimated impact of the good faith exception on employment levels commences a year prior to adoption and becomes puzzlingly large in subsequent years when state-specific trends are included, exceeding $10 \log$ points in years six forward. This pattern is very unlikely to reflect a causal relationship and suggests the presence of confounding shocks. A potential explanation is that California and Arizona, the two largest states that adopted a good faith exception, experienced unusually strong employment growth in the late 1980s, likely for reasons unrelated to this particular legal doctrine. ${ }^{27}$ The results for the public policy exception have inconsistent signs across specifications and show no evidence of a trend break after adoption of the doctrine. By contrast, results for the implied

\footnotetext{
${ }^{26}$ These results are robust to various specifications and to the exclusion of California and Arizona, even though Arizona had unusually high employment growth during the 1980s and 1990s.

${ }^{27}$ In fact, excluding California from the estimates largely eliminates the estimated positive employment effects of the good faith exception. However, California is arguably the strongest test-case for evaluating the labor market impact of this exception since the Cleary decision is the landmark case among good faith rulings. We are accordingly reluctant to remove California from the sample. Excluding Arizona reduces but does not eliminate the estimated positive employment effect.
} 
contract exception show consistently negative effects for both leads and lags, though the lead effects are smaller.

Table 6 shows results from regressions similar to equation (1) using LBD data, but where the dependent variable is the log of average manufacturing employment in state $s$ and industry $j$ over five-year intervals and where the wrongful discharge indicators take the value of 1 if the exceptions had been adopted as of the midpoint of the five-year intervals. Panel A presents results for all plants, while Panels B through D present results for continuing, entering and exiting plants, respectively. ${ }^{28}$

Consistent with the results from the ASM, which includes only continuing plants, we find that total employment in the LBD sample increased by about $7.8 \mathrm{log}$ points following the adoption the good faith exception. Examining employment separately for continuing, entering and exiting plants in Panels B through D shows that this growth is driven by continuing plants. Panel B shows a significant increase in employment of $8.3 \mathrm{log}$ points in continuing plants, while Panels $\mathrm{C}$ and D show a marginal decline in employment created by plant entry and an increase in employment lost due to plant exit, although these two effects are not statistically significant. Note also the close comparability of the estimated effects of the good faith exception on employment levels in the ASM sample (Table 5, Panel A) and on employment levels in ongoing plants in the LBD (Table 6, Panel B). This pattern is expected since the ASM sample is composed exclusively of ongoing plants. In summary, the net growth of employment that we observe after adoption of the good faith exception is accounted for by reduced job creation in entering plants and increased job destruction in exiting plans - both of which led to reduced employment - accompanied by more than offsetting employment growth in ongoing plants.

As with the ASM, the dynamic specifications in Appendix Table 3 show positive coefficients on the good faith exception's leads and implausibly large positive coefficients on the lags, making questionable a causal interpretation of the effects on employment. The results for the public policy and implied contract doctrines are comparable to the prior estimates. ${ }^{29}$

\footnotetext{
${ }^{28}$ Annual employment regressions yield quantitatively similar results, though the magnitudes of the coefficients are smaller. We use employment at five-year intervals here to keep consistency with the results on the counts of entering and exiting plants presented in the previous section.

${ }^{29}$ Table 6 also shows economically large, although inconsistent, effects of the public policy exception on employment levels. Similar to earlier studies, this pattern raises puzzles about the interpretation between the public policy exception and employment.
} 


\subsection{Productivity Effects}

The finding that the good faith exception reduces job flows is consistent with the expectation that this discharge protection raises firms' adjustments costs. Here we explore the consequences of this rise in adjustment costs on other margins of non-labor adjustment. One such margin is capital substitution; if discharge protections raise the effective price of labor by making it more expensive to hire and fire, firms may substitute towards other inputs. Second, given the restrictions on firms' ability to adjust, we also may expect total factor productivity to be affected - though as noted in Section (3), compositional shifts in worker hiring following the adoption of dismissal protections may generate countervailing effects on labor productivity.

We begin by examining whether productivity was affected by employment protections due to changes in input composition. In particular, we ask whether the introduction of employment protections affected capital investment and, subsequently, capital-labor ratios. Panels A and B of Table 7 report results of specifications similar to equations (1) and (3) without and with statespecific and industry-specific trends, but where the dependent variables are the log of total capital investment and the log of the capital-labor ratio.

Capital stocks are measured at the beginning-of-year and constructed using the perpetual inventory method. Capital stocks are separately calculated for machinery and structures and then aggregated for total capital metrics. The capital stock of plant $p$ in industry $j$ at time $t$ is:

$$
K_{p t}=\left(1-\delta_{j t-1}\right) K_{p t-1}+\frac{I_{p t-1}^{N}}{P_{I j t-1}^{N}}+\frac{I_{p t-1}^{U}}{P_{I j t-3}^{N}},
$$

where initial capital stocks in 1972 are obtained by deflating book values of capital by BEA twodigit SIC deflators for installed capital. New equipment investments, $I_{p t-1}^{N}$, are deflated with NBER four-digit SIC new-capital deflators, $P_{I j t-1}^{N}$. Used equipment purchases, $I_{p t-1}^{U}$, employ the NBER four-digit SIC deflators lagged three periods. The annual depreciation rates, $\delta_{j t-1}$, are obtained from the BEA by two-digit SIC industries.

Panel A of Table 7 shows a positive and significant effect of the introduction of the good faith exception on total investment (machinery and structures) of $6.5 \log$ points (Column 6) but show no effects from the introduction of the public policy and implied contract exceptions. Dynamic specifications in Appendix Table 4 indicate that capital investment peaks several years after adop- 
tion of the good faith exception and then declines somewhat thereafter (a pattern similar to the results for employment fluctuations). However, leads of the good faith adoption variable in the dynamic specifications are notably negative (though statistically insignificant), suggesting that part of the post-adoption rise in capital investment may reflect an investment rebound from an earlier downturn.

Not surprisingly given the increase in employment levels, Panel B of Table 7 shows mixedalbeit generally positive - effects of the good faith exception on capital-labor ratios. For example, estimated effects are negative when controlling for state-specific trends but become positive when controlling for plant effects. Dynamic specifications in Appendix Table 5 find negative coefficients on both leads and lags, raising the question of whether the introduction of the good faith exception followed rather than preceded increases in the capital-labor ratio.

To explore effects on productivity, Panel A of Table 8 presents results of specifications like equations (1) and (3), but where the dependent variables is a TFP measure estimated using a production function residual methodology. For the residuals methodology, we first estimate the following production function in logs for each two-digit SIC industry and year using ordinary least squares:

$$
\log \left(Y_{p t}\right)=\alpha+\varsigma_{j t} \log \left(L_{p t}\right)+\gamma_{j t} \log \left(H_{p t}\right)+\theta_{j t}^{M} \log \left(K_{p t}^{M}\right)+\theta_{j t}^{S} \log \left(K_{p t}^{S}\right)+\xi_{p t},
$$

where $Y_{p t}$ is value added (i.e., total value of shipments net of materials/fuels costs and inventory adjustments) in plant $p$ at time $t$ deflated using the NBER four-digit SIC shipments deflators, $L_{p t}$ is the count of production or unskilled workers, and $H_{p t}$ is the count of non-production or skilled workers. $K_{p t}^{M}$ and $K_{p t}^{S}$ are the separated machinery and structures capital stocks, respectively. The residuals from the regression above provide our TFP measure:

$$
T F P_{p t}=\log \left(Y_{p t}\right)-\widehat{\varsigma}_{j t} \log \left(L_{p t}\right)-\widehat{\gamma}_{j t} \log \left(H_{p t}\right)-\widehat{\theta}_{j t}^{M} \log \left(K_{p t}^{M}\right)-\widehat{\theta}_{j t}^{S} \log \left(K_{p t}^{S}\right)-\alpha
$$

The results in Table 8 show a uniformly negative and generally significant effect of the introduction of the good faith exception on TFP, though the effect is slightly attenuated when we control for plant effects. By contrast, the public policy exception appears to have a positive effect and the implied contract exception appears to have a negative effect, though neither is significant in 
any specification. ${ }^{30}$ However, results from dynamic specifications reported in Appendix Table 6 show mostly negative coefficients for both leads and lags of the good faith exception, though the coefficients on the lags are substantially larger. The dynamic specification thus raises some question about a causal interpretation of the good faith effects on productivity, though the available evidence is mostly consistent with a reduction in TFP in the four years following adoption of the good faith exception.

Finally, Panel B of Table 8 explores whether the increase in capital investment following the introduction of the good faith exception found in Table 7 affected labor productivity. We estimate that labor productivity rose substantially (by 1 to 4 log points) following adoption of the good faith exception. This measured rise in labor productivity follows from the fact that both capital investment and non-production worker employment (Tables 5 and 7) rose after adoption of the good faith exception. Since our labor productivity measure does not adjust for the quality of labor inputs, the rise in raw labor productivity is likely to reflect a mixture of capital deepening and compositional shifts in labor quality. Thus, this finding is not at odds with the conclusion that the good faith exception reduced TFP. Results from dynamic specifications for labor productivity that control for plant effects (Appendix Table 7) show negative coefficients on the leads and positive though insignificant coefficients on the lags, suggesting that the good faith exception preceded the increase in labor productivity.

\section{Conclusions}

This paper makes two contributions. The first is to exploit microdata to examine the effect of dismissal protections on establishment-level outcomes in a representative sample of employers. The second is to consider simultaneously the effects of these protections on job flows - where there are unambiguous theoretical implications - and on several other important (and mostly unstud-

\footnotetext{
${ }^{30}$ We also examined a cost-shares methodology to analyze TFP. Cost shares were estimated for three-digit SIC industries from the NBER productivity database (cf. Bartelsman and Gray 1996). Production worker, non-production worker, and materials and fuels cost shares are calculated relative to TVS; the cost share of capital is a residual such that the cost shares sum to one. The results of the TFP measure obtained using a cost-shares methodology are generally declining but more mixed. However, the cost-shares methodology presents several disadvantages: 1) the coefficients on the shares are out-of-sample estimates obtained using NBER data; 2) we cannot disaggregate between equipment and structures since the capital share is obtained as a residual; and 3) the cost-shares methodology assumes constant returns-to-scale in the production function and perfectly competitive input markets.
} 
ied) margins of firm behavior, including capital investment, labor productivity and total factor productivity, where the predictions of theory are less clear cut. We believe that the power of the analysis derives from the evidence that the adoption of one particular dismissal protection, the good faith exception to employment-at-will, reduced employment fluctuations in adopting states. These effects were largest in the first three years following adoption and diminished thereafter. This finding indicates that adjustment costs rose in the short-run, a necessary condition for there to be an impact on economic efficiency.

The finding on employment fluctuations motivates us to analyze how this short-run rise in adjustment costs impacted firms' choices of capital and labor inputs, and ultimately, their productivity. The most surprising result of our analysis is that the increase in adjustment costs appears to have spurred capital and skill deepening - that is, firms raised capital investment and increased non-production worker employment. These changes in input choices led to a rise in measured (nonquality-adjusted) labor productivity and a decline in total factor productivity. This last finding is potentially quite important because, if correct, it provides confirmation that exogenous increases in adjustment costs reduce efficiency.

Our findings also present two unresolved puzzles. First, the adoption of the good faith exception appears to follow (likely by coincidence) a major investment downturn. This pattern reduces our confidence in the causal interpretation of the rise in capital investment following adoption of the good faith exception. The second puzzle is that the estimated positive effect of the good faith exception on employment levels is larger than appears plausible (albeit often imprecisely estimated). In light of these puzzles, we view our findings as suggestive but inconclusive. Though our data support the hypothesis that adoption of the good faith exception raises adjustment costs, the anomalous results for employment levels suggests a cautious interpretation of the findings until further evidence accumulates.

Our results have interesting parallels with those of a recent study by Acemoglu and Finkelstein (2005) of firm-level responses to changes in labor costs in the U.S. hospital industry. Responding to a change in Medicare reimbursement policy in the 1980s that effectively increased the cost of labor relative to capital, Acemoglu-Finkelstein document that hospitals raised both their capitallabor ratios and the skill composition of their workforces. Acemoglu-Finkelstein suggest that this 
result may be explained by either capital-skill complementarity or technology-skill complementarity (assuming that new capital investments embed recent technologies), as in our discussion above. While the Acemoglu-Finkelstein findings are drawn from a distinctly different economic context than our study (i.e., a heavily regulated sector versus a relatively competitive sector) and exploit a different source of policy variation (i.e., employment subsidies rather than dismissal costs), the parallels with our findings for the effect of dismissal protections on the U.S. manufacturing sector are nonetheless intriguing and deserving of further consideration.

\section{References}

Acemoglu, Daron and Amy Finkelstein. 2005. "Input and Technology Choices in Regulated Industries: Evidence from the Health Care Sector." MIT Mimeograph, November.

Agell, Jonas. 1999. "On the Benefits from Rigid Labour Markets: Norms, Market Failures, and Social Insurance." The Economic Journal. 109, F143-F164.

Aghion, Phillipe and Benjamin Hermalin. 1990. "Legal Restrictions on Private Contracts can Enhance Efficiency." Journal of Law, Economics, and Organizations. 6(2), Fall, 381-409.

Autor, David H. 2003. "Outsourcing at Will: The Contribution of Unjust Dismissal Doctrine to the Growth of Employment Outsourcing." Journal of Labor Economics. 21(1), January, 1-42.

Autor, David H., John J. Donohue and Stewart J. Schwab. 2004. "The Employment Consequences of Wrongful-Discharge Laws: Large, Small, or None at All?" American Economic Review Papers and Proceedings. 93(2), May, 440-446.

Autor, David H., John J. Donohue and Stewart J. Schwab. 2006. "The Costs of WrongfulDischarge Laws." Review of Economics and Statistics, 88(2), May, 211-231.

Bartelsman, Eric and Wayne Gray. 1996. "The NBER Manufacturing Productivity Database." NBER Technical Working Paper 205.

Berman, Eli, John Bound and Zvi Griliches. 1994. "Changes in the Demand for Skilled Labor within U.S. Manufacturing Industries: Evidence from the Annual Survey of Manufactures." Quarterly Journal of Economics. 109, 367-397.

Bertola, Giuseppe. 2004. "A Pure Theory of Job Security and Labor Income Risk." Review of Economic Studies. 71(1), 43-61. 
Bird, Robert C. and John D. Knopf. 2005. "Do Wrongful Discharge Laws Impair Firm Performance?" University of Connecticut Mimeograph, November.

Blanchard, Olivier Jean and Pedro Portugal. 2001. "What Hides Behind an Unemployment Rate: Comparing Portuguese and U.S. Labor Markets." American Economic Review. 91(1), 187207.

Brügemann, Björn. 2006. "Employment Protection: Tough to Scrap or Tough to Get?" Working Paper.

Bureau of National Affairs. 1985. Employee Discipline and Discharge (Washington, DC: Bureau of National Affairs).

Davis, Steven, John Haltiwanger and Scott Schuh. 1996. Job Creation and Job Destruction (Cambridge, MA: MIT Press).

Dunne, Timothy, Mark Roberts and Larry Samuelson. 1989. "Patterns of Firm Entry and Exit in U.S. Manufacturing Industries." The RAND Journal of Economics. 19, 495-515.

Dertouzos, James N. and Lynn A. Karoly. 1992. Labor-Market Responses to Employer Liability (Santa Monica, CA: Rand).

Edelman, Lauren B., Steven E. Abraham and Howard S. Erlanger. 1992. "Professional Construction of Law: The Inflated Threat of Wrongful-Discharge." Law E Society Review. 26, 47-83.

Ewing, Bradley T., Charles M. North and Beck A. Tayler. 2005. "The Employment Effects of a "Good Cause" Discharge Standard in Montana." Industrial and Labor Relations Review. 59(1), October, 17-33.

Griliches, Zvi. 1969. "Capital-Skill Complementarity." Review of Economics and Statistics. 51, 465-68.

Grout, Paul. 1984. "Investment and Wages in the Absence of Binding Contracts: A Nash Bargaining Approach." Econometrica. 52, 449-460.

Jarmin, Ronald and Javier Miranda. 2002. "The Longitudinal Business Database." CES Working Paper.

Jung, David J. and Richard Harkness. 1989. "Life After Foley: The Future of Wrongful Discharge Litigation." Hastings Law Journal. 41(6), November, 131-149.

Khan, Lawrence. 2006. "The Impact of Employment Protection Mandates on Demographic 
Temporary Employment Patterns: International Microeconomic Evidence." Working Paper.

Kerr, William and Ramana Nanda. 2006. "Banking Deregulation, Financing Constraints, and Entrepreneurship." Harvard Business School Working Paper 07-033.

Koeniger, Winfried and Julien Prat. 2006. "Employment Protection, Product Market Regulation and Firm Selection." Working Paper.

Kugler, Adriana and Giovanni Pica. Forthcoming. "Effects of Employment Protection on Job and Workers Flows: Evidence from the 1990 Italian Reform." Labour Economics.

Kugler, Adriana and Gilles Saint-Paul. 2004. "How Do Firing Costs Affect Worker Flows in a World with Adverse Selection?" Journal of Labor Economics. 22(3), 553-584.

Kugler, Adriana, Juan F. Jimeno and Virginia Hernanz. 2003. "Employment Consequences of Restrictive Permanent Contracts: Evidence from Spanish Labor Market Reforms." CEPR Discussion Paper No. 3724.

Lazear, Edward P. 1990. "Job Security Provisions and Employment." Quarterly Journal of Economics. 105(3), 699-726.

Levine, David I. 1991. "Just-Cause Employment Policies in the Presence of Worker Adverse Selection." Journal of Labor Economics. 9, 294-305.

Macleod, W. Bentley and Voraprapa Nakavachara. 2006. "Default Rules: The Case of Wrongful Discharge Laws." Working Paper.

Miles, Thomas J. 2000. "Common Law Exceptions to Employment at Will and U.S. Labor Markets." Journal of Law, Economics, and Organizations. 16(1), 74-101.

Morriss, Andrew P. 1994. "Exploding Myths: An Empirical and Economic Reassessment of the Rise of Employment-At-Will." Missouri Law Review. 59, 679-771.

Morriss, Andrew P. 1995. "Developing a Framework for Empirical Research on the Common Law: General Principles and Case Studies of the Decline of Employment-At-Will." Case Western Reserve Law Review. 45(4), Spring, 999-1148.

Mortensen, Dale T. and Christopher A. Pissarides. 1994. "Job Creation and Job Destruction in the Theory of Unemployment." Review of Economic Studies. 61(3), 397-415.

Petrin, Amil, and Jagadeesh Sivadasan. 2006. "Job Security Does Affect Economic Efficiency: Theory, A New Statistic, and Evidence from Chile." NBER Working Paper No. 12757. 
Pissarides, Christopher A. 2000. Equilibrium Unemployment Theory (Cambridge, MA: MIT Press).

Prieger, James E. 2005. "The Impact of the Americans with Disabilities Act on the Entry and Exit of Retail Firms." Working Paper.

Saint-Paul, Gilles. 2002. "The Political Economy of Employment Protection." Journal of Political Economy. 110(3), 672-704.

Schanzenbach, Max. 2003. "Exceptions to Employment at Will: Raising Firing Costs or Enforcing Life-Cycle Contracts?" American Law and Economics Review. 5(2), August, 470-504.

Summers, Lawrence H. 1989. "Some Simple Economics of Mandated Benefits." American Economic Review. 79(2), May, 177-183.

Sutton, John R. and Frank Dobbin. 1996. "The Two Faces of Governance: Response to Legal Uncertainty in American Firms, 1955-1985." American Journal of Sociology. 61(5), 794-811.

Wasmer, Etienne. 2006. "Interpreting Europe-U.S. Labor Market Differences: The Specificity of Human Capital Investments." American Economic Review. 96(3), June, 811-831.

Wolfers, Justin. 2005. "Measuring the Effects of Employment Protection on Job Flows: Evidence from Seasonal Cycles." Wharton School of Business Mimeograph, January. 
Figure 1: Count of States Recognizing Exceptions to Employment-at-Will, 1970-1999 at Monthly Frequency

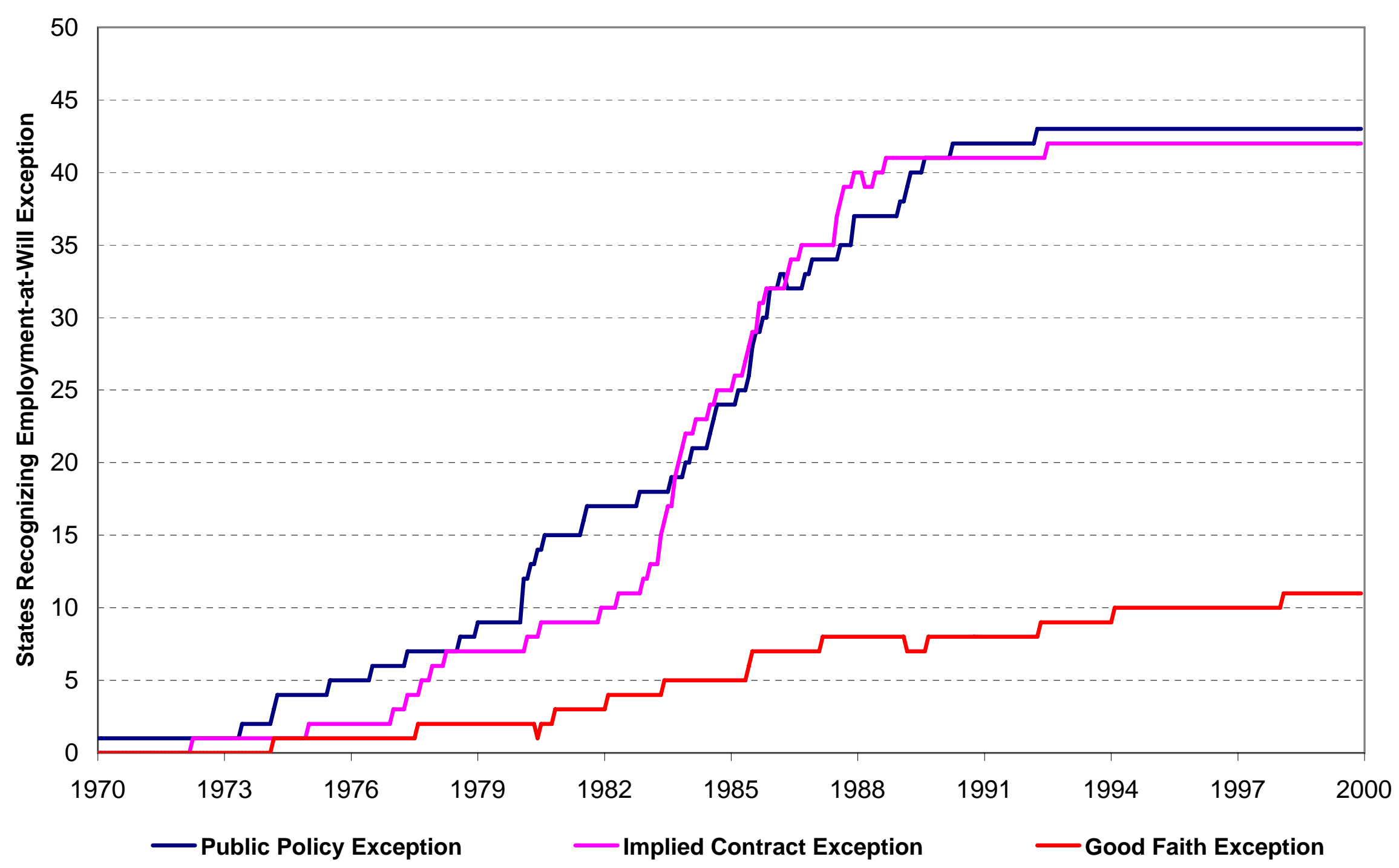


Table 1: Descriptive Statistics for LBD and ASM, 1976-1999

\begin{tabular}{|c|c|c|c|c|c|}
\hline \multirow{3}{*}{ Annual Means of Variable } & \multicolumn{4}{|c|}{ Covered by Exceptions } & \multirow[b]{2}{*}{$\begin{array}{c}\text { All } \\
\text { States }\end{array}$} \\
\hline & $\begin{array}{l}\text { Good } \\
\text { Faith }\end{array}$ & $\begin{array}{l}\text { Public } \\
\text { Policy }\end{array}$ & $\begin{array}{l}\text { Implied } \\
\text { Contract }\end{array}$ & $\begin{array}{c}\text { Never } \\
\text { Covered }\end{array}$ & \\
\hline & $(1)$ & $(2)$ & (3) & (4) & (5) \\
\hline & \multicolumn{5}{|c|}{ A. LBD State-SIC2 Panel } \\
\hline Employment Change & $13 \%$ & $11 \%$ & $11 \%$ & $10 \%$ & $11 \%$ \\
\hline \% Positive Change & $57 \%$ & $58 \%$ & $58 \%$ & $60 \%$ & $58 \%$ \\
\hline Surveyed Employment & $15,078,526$ & $55,598,270$ & $56,151,488$ & $5,387,148$ & $68,091,479$ \\
\hline \% Manufacturing & $25 \%$ & $28 \%$ & $28 \%$ & $21 \%$ & $28 \%$ \\
\hline \% Mining & $1 \%$ & $1 \%$ & $1 \%$ & $0 \%$ & $1 \%$ \\
\hline$\%$ Construction & $7 \%$ & $7 \%$ & $7 \%$ & $8 \%$ & $7 \%$ \\
\hline \% Wholesale Trade & $8 \%$ & $8 \%$ & $8 \%$ & $9 \%$ & $8 \%$ \\
\hline \% Retail Trade & $26 \%$ & $26 \%$ & $26 \%$ & $29 \%$ & $26 \%$ \\
\hline \% Services & $32 \%$ & $29 \%$ & $30 \%$ & $32 \%$ & $30 \%$ \\
\hline \% in Entering Establishments & $8 \%$ & $7 \%$ & $7 \%$ & $8 \%$ & $7 \%$ \\
\hline \% in Exiting Establishements & $7 \%$ & $6 \%$ & $6 \%$ & $7 \%$ & $6 \%$ \\
\hline \% Part of Multi-Unit Firms & $53 \%$ & $56 \%$ & $55 \%$ & $53 \%$ & $55 \%$ \\
\hline Surveyed Establishments & 869,860 & $3,106,760$ & $3,188,694$ & 333,504 & 3,871,392 \\
\hline Establishment Entry Rate & $14 \%$ & $13 \%$ & $13 \%$ & $15 \%$ & $13 \%$ \\
\hline Establishment Exit Rate & $12 \%$ & $11 \%$ & $11 \%$ & $12 \%$ & $11 \%$ \\
\hline \% Part of Multi-Unit Firms & $21 \%$ & $23 \%$ & $22 \%$ & $23 \%$ & $22 \%$ \\
\hline \multirow[t]{2}{*}{ Maximum States } & 12 & 43 & 43 & 3 & 50 \\
\hline & \multicolumn{5}{|c|}{ B. ASM Manufacturing Plant Panel } \\
\hline Plant Employment Change & $11 \%$ & $11 \%$ & $11 \%$ & $10 \%$ & $11 \%$ \\
\hline \% Positive Change & $49 \%$ & $49 \%$ & $49 \%$ & $50 \%$ & $49 \%$ \\
\hline Plant Employment & 790 & 747 & 766 & 658 & 746 \\
\hline \% Non-Production Workers & $32 \%$ & $26 \%$ & $27 \%$ & $25 \%$ & $26 \%$ \\
\hline$\%$ Part of Multi-Unit Firm & $98 \%$ & $98 \%$ & $98 \%$ & $97 \%$ & $98 \%$ \\
\hline Total Installed Capital (m) & $\$ 33$ & $\$ 30$ & $\$ 31$ & $\$ 27$ & $\$ 31$ \\
\hline Total Investment (m) & $\$ 1.9$ & $\$ 1.7$ & $\$ 1.7$ & $\$ 1.5$ & $\$ 1.7$ \\
\hline Labor Productivity (k) & $\$ 88$ & $\$ 86$ & $\$ 87$ & $\$ 78$ & $\$ 85$ \\
\hline Maximum Plants & 794 & 4,848 & 4,601 & 323 & 5,666 \\
\hline
\end{tabular}

Notes: Annual means for Columns 1-3 are calculated over all observations covered by the listed exception during the sample period, including any pre-coverage and post-coverage periods. Figures employ NBER deflators as described in text and are presented in 1999 dollars. 
Table 2: Effects of Employment-at-Will Doctrines on

LBD Annual Employment Changes, 1976-1999

\begin{tabular}{lcccc}
\hline \multirow{2}{*}{$\begin{array}{c}\text { Legal } \\
\text { Exception }\end{array}$} & $\begin{array}{c}\text { State FE, } \\
\text { SIC2 FE, } \\
\text { YR FE }\end{array}$ & $\begin{array}{c}\text { Col. 1 plus } \\
\text { State Trends }\end{array}$ & $\begin{array}{c}\text { Col. 1 plus } \\
\text { SIC2-YR FE }\end{array}$ & $\begin{array}{c}\text { Col. 1 plus } \\
\text { State Trends, } \\
\text { SIC2-YR FE }\end{array}$ \\
\cline { 2 - 5 } Good & A. LBD Absolute & Annual Employment Changes, Full Sample \\
Faith & -0.005 & -0.006 & -0.004 & -0.005 \\
Public & $(0.003)$ & $(0.004)$ & $(0.003)$ & $(0.004)$ \\
Policy & 0.002 & 0.003 & 0.002 & 0.004 \\
Implied & $(0.002)$ & $(0.003)$ & $(0.002)$ & $(0.003)$ \\
Contract & 0.000 & 0.001 & 0.001 & 0.002 \\
Obs. & $(0.002)$ & $(0.002)$ & $(0.002)$ & $(0.002)$ \\
& 51,074 & 51,074 & 51,074 & 51,074 \\
Good & B. LBD Absolute Annual Employment Changes, Mfg. Only & & \\
Faith & -0.009 & -0.016 & -0.006 & -0.013 \\
Public & $(0.005)$ & $(0.007)$ & $(0.005)$ & $(0.007)$ \\
Policy & 0.006 & 0.010 & 0.006 & 0.011 \\
Implied & $(0.003)$ & $(0.003)$ & $(0.003)$ & $(0.003)$ \\
Contract & 0.000 & 0.003 & 0.002 & 0.005 \\
Obs. & $(0.003)$ & $(0.004)$ & $(0.003)$ & $(0.004)$ \\
\hline & 21,418 & 21,418 & 21,418 & 21,418 \\
\hline
\end{tabular}

Notes: Huber-White robust standard errors clustered on state reported in parentheses. 
Table 3A: Effects of Employment-at-Will Doctrines on ASM Annual and Quarterly Employment Changes, 1976-1999

\begin{tabular}{|c|c|c|c|c|c|c|}
\hline \multirow[t]{2}{*}{$\begin{array}{c}\text { Legal } \\
\text { Exception }\end{array}$} & $\begin{array}{l}\text { State FE, } \\
\text { SIC2 FE, } \\
\text { YR FE }\end{array}$ & $\begin{array}{l}\text { Col. } 1 \text { plus } \\
\text { State Trends }\end{array}$ & $\begin{array}{l}\text { Col. } 1 \text { plus } \\
\text { SIC2-YR FE }\end{array}$ & $\begin{array}{l}\text { Col. } 1 \text { plus } \\
\text { State Trends, } \\
\text { SIC2-YR FE }\end{array}$ & $\begin{array}{l}\text { Plant FE, } \\
\text { YR FE }\end{array}$ & $\begin{array}{l}\text { Col. } 5 \text { plus } \\
\text { State Trends, } \\
\text { SIC2-YR FE }\end{array}$ \\
\hline & (1) & $(2)$ & (3) & (4) & (5) & (6) \\
\hline & \multicolumn{6}{|c|}{ A. ASM Absolute Annual Employment Changes } \\
\hline $\begin{array}{l}\text { Good } \\
\text { Faith }\end{array}$ & $\begin{array}{l}-0.004 \\
(0.004)\end{array}$ & $\begin{array}{l}-0.005 \\
(0.003)\end{array}$ & $\begin{array}{l}-0.003 \\
(0.004)\end{array}$ & $\begin{array}{l}-0.005 \\
(0.003)\end{array}$ & $\begin{array}{l}-0.006 \\
(0.004)\end{array}$ & $\begin{array}{l}-0.002 \\
(0.004)\end{array}$ \\
\hline $\begin{array}{l}\text { Public } \\
\text { Policy }\end{array}$ & $\begin{array}{c}0.000 \\
(0.003)\end{array}$ & $\begin{array}{c}0.001 \\
(0.003)\end{array}$ & $\begin{array}{l}-0.001 \\
(0.002)\end{array}$ & $\begin{array}{c}0.000 \\
(0.003)\end{array}$ & $\begin{array}{c}0.000 \\
(0.003)\end{array}$ & $\begin{array}{c}-0.001 \\
(0.002)\end{array}$ \\
\hline $\begin{array}{l}\text { Implied } \\
\text { Contract }\end{array}$ & $\begin{array}{c}0.000 \\
(0.002)\end{array}$ & $\begin{array}{c}0.004 \\
(0.002)\end{array}$ & $\begin{array}{c}0.001 \\
(0.002)\end{array}$ & $\begin{array}{c}0.003 \\
(0.002)\end{array}$ & $\begin{array}{l}-0.001 \\
(0.003)\end{array}$ & $\begin{array}{c}0.001 \\
(0.002)\end{array}$ \\
\hline \multirow[t]{2}{*}{ Obs. } & 135,937 & 135,937 & 135,937 & 135,937 & 135,937 & 135,937 \\
\hline & \multicolumn{6}{|c|}{ B. ASM Production Worker Quarterly Churn } \\
\hline $\begin{array}{l}\text { Good } \\
\text { Faith }\end{array}$ & $\begin{array}{l}-0.005 \\
(0.009)\end{array}$ & $\begin{array}{c}0.005 \\
(0.006)\end{array}$ & $\begin{array}{l}-0.003 \\
(0.008)\end{array}$ & $\begin{array}{c}0.006 \\
(0.005)\end{array}$ & $\begin{array}{l}-0.004 \\
(0.009)\end{array}$ & $\begin{array}{c}0.004 \\
(0.003)\end{array}$ \\
\hline $\begin{array}{l}\text { Public } \\
\text { Policy }\end{array}$ & $\begin{array}{c}0.005 \\
(0.004)\end{array}$ & $\begin{array}{c}0.003 \\
(0.003)\end{array}$ & $\begin{array}{c}0.003 \\
(0.003)\end{array}$ & $\begin{array}{c}0.003 \\
(0.003)\end{array}$ & $\begin{array}{c}0.005 \\
(0.004)\end{array}$ & $\begin{array}{c}0.004 \\
(0.004)\end{array}$ \\
\hline $\begin{array}{l}\text { Implied } \\
\text { Contract }\end{array}$ & $\begin{array}{c}-0.004 \\
(0.005)\end{array}$ & $\begin{array}{l}-0.003 \\
(0.004)\end{array}$ & $\begin{array}{l}-0.002 \\
(0.003)\end{array}$ & $\begin{array}{l}-0.003 \\
(0.003)\end{array}$ & $\begin{array}{c}-0.004 \\
(0.005)\end{array}$ & $\begin{array}{c}-0.002 \\
(0.003)\end{array}$ \\
\hline Obs. & 135,976 & 135,976 & 135,976 & 135,976 & 135,976 & 135,976 \\
\hline
\end{tabular}

Notes: Huber-White robust standard errors clustered on state reported in parentheses. 
Table 3B: Dynamic Effects of Employment-at-Will Doctrines on

ASM Absolute Annual Employment Changes, 1976-1999

\begin{tabular}{|c|c|c|c|c|c|c|c|c|c|c|c|c|}
\hline \multirow{3}{*}{$\begin{array}{c}\text { Legal } \\
\text { Exception } \\
\Delta \text { GF t+2 }\end{array}$} & \multicolumn{2}{|c|}{$\begin{array}{l}\text { State FE, } \\
\text { SIC2 FE, } \\
\text { YR FE }\end{array}$} & \multicolumn{2}{|c|}{$\begin{array}{l}\text { Col. } 1 \text { plus } \\
\text { State Trends }\end{array}$} & \multicolumn{2}{|c|}{$\begin{array}{l}\text { Col. } 1 \text { plus } \\
\text { SIC2-YR FE }\end{array}$} & \multicolumn{2}{|c|}{$\begin{array}{l}\text { Col. } 1 \text { plus } \\
\text { State Trends, } \\
\text { SIC2-YR FE }\end{array}$} & \multicolumn{2}{|c|}{$\begin{array}{c}\text { Plant FE, } \\
\text { YR FE }\end{array}$} & \multicolumn{2}{|c|}{$\begin{array}{l}\text { Col. } 5 \text { plus } \\
\text { State Trends, } \\
\text { SIC2-YR FE }\end{array}$} \\
\hline & \multicolumn{2}{|c|}{ (1) } & \multicolumn{2}{|c|}{ (2) } & \multicolumn{2}{|c|}{ (3) } & \multicolumn{2}{|c|}{ (4) } & \multicolumn{2}{|c|}{$(5)$} & \multicolumn{2}{|c|}{ (6) } \\
\hline & 0.011 & $(0.011)$ & 0.014 & $(0.010)$ & 0.008 & $(0.011)$ & 0.013 & $(0.010)$ & 0.009 & $(0.010)$ & 0.010 & $(0.011)$ \\
\hline$\Delta \mathrm{GF} \mathrm{t}+1$ & 0.006 & $(0.011)$ & 0.010 & $(0.011)$ & 0.005 & $(0.011)$ & 0.010 & $(0.010)$ & 0.004 & $(0.011)$ & 0.007 & $(0.010)$ \\
\hline$\Delta \mathrm{GF}$ & 0.004 & $(0.006)$ & 0.009 & $(0.007)$ & 0.001 & $(0.005)$ & 0.006 & $(0.006)$ & 0.001 & $(0.006)$ & 0.003 & $(0.005)$ \\
\hline$\Delta \mathrm{GF} \mathrm{t}-1$ & 0.004 & $(0.006)$ & 0.010 & $(0.007)$ & 0.002 & $(0.006)$ & 0.009 & $(0.007)$ & 0.001 & $(0.006)$ & 0.004 & $(0.005)$ \\
\hline$\Delta \mathrm{GF} \mathrm{t}-2$ & -0.001 & $(0.005)$ & 0.005 & $(0.007)$ & -0.003 & $(0.005)$ & 0.004 & $(0.006)$ & -0.004 & $(0.005)$ & 0.000 & $(0.005)$ \\
\hline$\Delta \mathrm{GF} \mathrm{t}-3$ & -0.017 & $(0.006)$ & -0.010 & $(0.007)$ & -0.016 & $(0.007)$ & -0.008 & $(0.008)$ & -0.021 & $(0.006)$ & -0.013 & $(0.006)$ \\
\hline$\Delta \mathrm{GF} \mathrm{t}-4$ & -0.013 & $(0.007)$ & -0.005 & $(0.007)$ & -0.012 & $(0.007)$ & -0.004 & $(0.006)$ & -0.016 & $(0.007)$ & -0.009 & $(0.005)$ \\
\hline$\Delta \mathrm{GF} \mathrm{t}-5$ & -0.007 & $(0.007)$ & 0.003 & $(0.006)$ & -0.005 & $(0.007)$ & 0.004 & $(0.005)$ & -0.010 & $(0.007)$ & -0.002 & $(0.006)$ \\
\hline GF Lag t-6 & 0.001 & $(0.006)$ & 0.015 & $(0.008)$ & 0.002 & $(0.006)$ & 0.015 & $(0.006)$ & -0.002 & $(0.006)$ & 0.005 & $(0.005)$ \\
\hline$\Delta \mathrm{PP} \mathrm{t}+2$ & -0.005 & $(0.004)$ & -0.003 & $(0.004)$ & -0.005 & $(0.004)$ & -0.004 & $(0.004)$ & -0.005 & $(0.004)$ & -0.005 & $(0.004)$ \\
\hline$\Delta \mathrm{PP} \mathrm{t}+1$ & 0.000 & $(0.002)$ & 0.002 & $(0.003)$ & -0.001 & $(0.003)$ & 0.001 & $(0.003)$ & 0.000 & $(0.002)$ & -0.001 & $(0.003)$ \\
\hline$\Delta \mathrm{PP}$ & 0.005 & $(0.003)$ & 0.008 & $(0.003)$ & 0.003 & $(0.003)$ & 0.006 & $(0.003)$ & 0.005 & $(0.003)$ & 0.003 & $(0.003)$ \\
\hline$\Delta \mathrm{PP}$ t-1 & 0.005 & $(0.003)$ & 0.008 & $(0.003)$ & 0.003 & $(0.003)$ & 0.006 & $(0.003)$ & 0.005 & $(0.003)$ & 0.003 & $(0.003)$ \\
\hline$\Delta \mathrm{PP}$ t-2 & 0.001 & $(0.004)$ & 0.005 & $(0.005)$ & -0.002 & $(0.003)$ & 0.002 & $(0.004)$ & 0.001 & $(0.004)$ & -0.002 & $(0.003)$ \\
\hline$\Delta \mathrm{PP}$ t-3 & 0.003 & $(0.003)$ & 0.006 & $(0.004)$ & 0.001 & $(0.003)$ & 0.004 & $(0.004)$ & 0.002 & $(0.003)$ & 0.001 & $(0.003)$ \\
\hline$\Delta \mathrm{PP} \mathrm{t}-4$ & 0.007 & $(0.003)$ & 0.010 & $(0.004)$ & 0.003 & $(0.003)$ & 0.006 & $(0.004)$ & 0.006 & $(0.003)$ & 0.003 & $(0.003)$ \\
\hline$\Delta \mathrm{PP} \mathrm{t}-5$ & 0.001 & $(0.003)$ & 0.005 & $(0.004)$ & -0.003 & $(0.003)$ & 0.001 & $(0.004)$ & 0.000 & $(0.003)$ & -0.003 & $(0.003)$ \\
\hline PP Lag t-6 & 0.004 & $(0.004)$ & 0.010 & $(0.005)$ & 0.001 & $(0.003)$ & 0.007 & $(0.004)$ & 0.003 & $(0.004)$ & 0.001 & $(0.003)$ \\
\hline$\Delta \mathrm{IC} \mathrm{t}+2$ & 0.002 & $(0.004)$ & 0.004 & $(0.004)$ & 0.001 & $(0.003)$ & 0.003 & $(0.004)$ & 0.001 & $(0.004)$ & 0.001 & $(0.004)$ \\
\hline$\Delta \mathrm{IC} \mathrm{t}+1$ & -0.002 & $(0.003)$ & 0.001 & $(0.003)$ & -0.001 & $(0.003)$ & 0.001 & $(0.003)$ & -0.002 & $(0.003)$ & -0.001 & $(0.003)$ \\
\hline$\Delta \mathrm{IC}$ & 0.004 & $(0.004)$ & 0.007 & $(0.004)$ & 0.004 & $(0.003)$ & 0.007 & $(0.004)$ & 0.003 & $(0.004)$ & 0.004 & $(0.004)$ \\
\hline$\Delta \mathrm{IC} \mathrm{t}-1$ & 0.003 & $(0.004)$ & 0.007 & $(0.005)$ & 0.003 & $(0.004)$ & 0.006 & $(0.005)$ & 0.003 & $(0.004)$ & 0.002 & $(0.004)$ \\
\hline$\Delta \mathrm{IC} \mathrm{t}-2$ & 0.007 & $(0.004)$ & 0.012 & $(0.005)$ & 0.008 & $(0.003)$ & 0.012 & $(0.005)$ & 0.006 & $(0.003)$ & 0.008 & $(0.003)$ \\
\hline$\Delta \mathrm{IC} \mathrm{t}-3$ & 0.003 & $(0.003)$ & 0.008 & $(0.005)$ & 0.002 & $(0.003)$ & 0.007 & $(0.004)$ & 0.002 & $(0.004)$ & 0.002 & $(0.003)$ \\
\hline$\Delta \mathrm{IC} \mathrm{t}-4$ & -0.003 & $(0.004)$ & 0.003 & $(0.005)$ & -0.002 & $(0.003)$ & 0.002 & $(0.005)$ & -0.004 & $(0.004)$ & -0.002 & $(0.003)$ \\
\hline$\Delta \mathrm{IC} \mathrm{t}-5$ & -0.003 & $(0.004)$ & 0.004 & $(0.005)$ & -0.001 & $(0.003)$ & 0.004 & $(0.005)$ & -0.003 & $(0.004)$ & -0.001 & $(0.004)$ \\
\hline IC Lag t-6 & -0.003 & $(0.004)$ & 0.006 & $(0.006)$ & -0.001 & $(0.003)$ & 0.005 & $(0.006)$ & -0.004 & $(0.004)$ & -0.001 & $(0.003)$ \\
\hline Obs. & 13 & 37 & 135 & 37 & 13 & 37 & & 37 & 13 & 37 & & 37 \\
\hline
\end{tabular}

Notes: Huber-White robust standard errors clustered on state reported in parentheses. 
Table 3C: Dynamic Effects of Employment-at-Will Doctrines on

ASM Production Worker Quarterly Churn, 1976-1999

\begin{tabular}{|c|c|c|c|c|c|c|c|c|c|c|c|c|}
\hline \multirow{3}{*}{$\begin{array}{c}\text { Legal } \\
\text { Exception }\end{array}$} & \multicolumn{2}{|c|}{$\begin{array}{c}\text { State FE, } \\
\text { SIC2 FE, } \\
\text { YR FE }\end{array}$} & \multicolumn{2}{|c|}{$\begin{array}{l}\text { Col. } 1 \text { plus } \\
\text { State Trends }\end{array}$} & \multicolumn{2}{|c|}{$\begin{array}{l}\text { Col. } 1 \text { plus } \\
\text { SIC2-YR FE }\end{array}$} & \multicolumn{2}{|c|}{$\begin{array}{l}\text { Col. } 1 \text { plus } \\
\text { State Trends, } \\
\text { SIC2-YR FE }\end{array}$} & \multicolumn{2}{|c|}{$\begin{array}{l}\text { Plant FE, } \\
\text { YR FE }\end{array}$} & \multicolumn{2}{|c|}{$\begin{array}{c}\text { Col. } 5 \text { plus } \\
\text { State Trends, } \\
\text { SIC2-YR FE }\end{array}$} \\
\hline & \multicolumn{2}{|c|}{$(1)$} & \multicolumn{2}{|c|}{ (2) } & \multicolumn{2}{|c|}{ (3) } & \multicolumn{2}{|c|}{ (4) } & \multicolumn{2}{|c|}{$(5)$} & \multicolumn{2}{|c|}{ (6) } \\
\hline & -0.003 & $(0.011)$ & 0.008 & $(0.007)$ & -0.005 & $(0.010)$ & 0.006 & $(0.007)$ & -0.001 & $(0.011)$ & 0.003 & $(0.007)$ \\
\hline$\Delta \mathrm{GF} t+1$ & 0.009 & $(0.015)$ & 0.024 & $(0.017)$ & 0.006 & $(0.014)$ & 0.020 & $(0.017)$ & 0.011 & $(0.015)$ & 0.015 & $(0.014)$ \\
\hline$\Delta \mathrm{GF}$ & -0.026 & $(0.014)$ & -0.011 & $(0.013)$ & -0.027 & $(0.013)$ & -0.013 & $(0.012)$ & -0.025 & $(0.014)$ & -0.019 & $(0.008)$ \\
\hline$\Delta \mathrm{GF}$ t-1 & -0.017 & $(0.015)$ & 0.000 & $(0.011)$ & -0.018 & $(0.013)$ & -0.002 & $(0.010)$ & -0.015 & $(0.015)$ & -0.009 & (0.007) \\
\hline$\Delta \mathrm{GF} \mathrm{t}-2$ & -0.015 & $(0.014)$ & 0.005 & $(0.011)$ & -0.011 & $(0.014)$ & 0.006 & $(0.010)$ & -0.013 & $(0.014)$ & 0.000 & $(0.008)$ \\
\hline$\Delta \mathrm{GF} \mathrm{t}-3$ & -0.029 & $(0.015)$ & -0.008 & $(0.011)$ & -0.025 & $(0.013)$ & -0.007 & $(0.010)$ & -0.027 & $(0.016)$ & -0.014 & (0.007) \\
\hline$\Delta \mathrm{GF} \mathrm{t}-4$ & 0.014 & $(0.017)$ & 0.036 & $(0.011)$ & 0.020 & $(0.016)$ & 0.039 & $(0.013)$ & 0.016 & $(0.018)$ & 0.032 & $(0.010)$ \\
\hline$\Delta \mathrm{GF} t-5$ & -0.002 & $(0.029)$ & 0.021 & $(0.019)$ & 0.003 & $(0.027)$ & 0.022 & $(0.017)$ & 0.000 & $(0.030)$ & 0.015 & $(0.021)$ \\
\hline GF Lag t-6 & -0.011 & $(0.014)$ & 0.013 & $(0.013)$ & -0.009 & $(0.013)$ & 0.011 & $(0.013)$ & -0.008 & $(0.014)$ & 0.002 & $(0.007)$ \\
\hline$\Delta \mathrm{PP} \mathrm{t}+2$ & -0.003 & $(0.005)$ & -0.004 & $(0.005)$ & -0.004 & $(0.005)$ & -0.006 & $(0.005)$ & -0.003 & $(0.005)$ & -0.003 & $(0.005)$ \\
\hline$\Delta \mathrm{PP} \mathrm{t}+1$ & 0.006 & $(0.006)$ & 0.003 & $(0.005)$ & 0.002 & $(0.004)$ & -0.001 & $(0.005)$ & 0.006 & $(0.006)$ & 0.003 & $(0.005)$ \\
\hline$\Delta \mathrm{PP}$ & 0.004 & $(0.008)$ & 0.000 & $(0.007)$ & -0.001 & $(0.007)$ & -0.004 & $(0.007)$ & 0.004 & $(0.008)$ & 0.001 & $(0.007)$ \\
\hline$\Delta \mathrm{PP} \mathrm{t}-1$ & 0.003 & $(0.006)$ & -0.003 & $(0.006)$ & 0.000 & $(0.005)$ & -0.005 & $(0.006)$ & 0.003 & $(0.006)$ & 0.001 & $(0.005)$ \\
\hline$\Delta \mathrm{PP} \mathrm{t}-2$ & 0.005 & $(0.006)$ & -0.001 & $(0.006)$ & 0.001 & $(0.005)$ & -0.003 & $(0.006)$ & 0.004 & $(0.006)$ & 0.003 & $(0.005)$ \\
\hline$\Delta \mathrm{PP} \mathrm{t}-3$ & 0.009 & $(0.006)$ & 0.003 & $(0.006)$ & 0.004 & $(0.005)$ & -0.001 & $(0.006)$ & 0.009 & $(0.007)$ & 0.006 & $(0.005)$ \\
\hline$\Delta \mathrm{PP} \mathrm{t}-4$ & 0.011 & $(0.007)$ & 0.005 & $(0.007)$ & 0.005 & $(0.006)$ & 0.001 & $(0.007)$ & 0.010 & $(0.008)$ & 0.008 & $(0.007)$ \\
\hline$\Delta \mathrm{PP} t-5$ & 0.007 & $(0.008)$ & 0.001 & $(0.007)$ & 0.005 & $(0.006)$ & 0.000 & $(0.007)$ & 0.007 & $(0.008)$ & 0.007 & $(0.006)$ \\
\hline PP Lag t-6 & 0.009 & $(0.008)$ & 0.005 & $(0.008)$ & 0.004 & $(0.006)$ & 0.001 & $(0.007)$ & 0.009 & $(0.008)$ & 0.008 & $(0.006)$ \\
\hline$\Delta \mathrm{IC} \mathrm{t}+2$ & 0.005 & $(0.006)$ & 0.005 & $(0.006)$ & 0.005 & $(0.005)$ & 0.004 & $(0.005)$ & 0.005 & $(0.006)$ & 0.005 & $(0.005)$ \\
\hline$\Delta \mathrm{IC} \mathrm{t}+1$ & 0.001 & $(0.005)$ & 0.000 & $(0.005)$ & 0.004 & $(0.005)$ & 0.002 & $(0.005)$ & 0.001 & $(0.005)$ & 0.004 & $(0.006)$ \\
\hline$\Delta \mathrm{IC}$ & -0.004 & $(0.006)$ & -0.006 & $(0.007)$ & -0.006 & $(0.006)$ & -0.009 & $(0.006)$ & -0.004 & $(0.006)$ & -0.007 & $(0.006)$ \\
\hline$\Delta \mathrm{IC} \mathrm{t}-1$ & 0.003 & $(0.006)$ & 0.001 & $(0.006)$ & 0.003 & $(0.006)$ & -0.001 & $(0.006)$ & 0.003 & $(0.006)$ & 0.002 & $(0.006)$ \\
\hline$\Delta \mathrm{IC} \mathrm{t}-2$ & -0.001 & $(0.006)$ & -0.002 & $(0.007)$ & 0.000 & $(0.005)$ & -0.004 & $(0.006)$ & -0.001 & $(0.006)$ & -0.001 & $(0.005)$ \\
\hline$\Delta \mathrm{IC} \mathrm{t}-3$ & -0.004 & $(0.006)$ & -0.005 & $(0.005)$ & -0.003 & $(0.005)$ & -0.007 & $(0.005)$ & -0.004 & $(0.006)$ & -0.003 & $(0.005)$ \\
\hline$\Delta \mathrm{IC} \mathrm{t}-4$ & -0.007 & $(0.006)$ & -0.007 & $(0.006)$ & -0.005 & $(0.005)$ & -0.008 & $(0.006)$ & -0.007 & $(0.006)$ & -0.005 & $(0.005)$ \\
\hline$\Delta \mathrm{IC} \mathrm{t}-5$ & -0.003 & $(0.008)$ & -0.003 & $(0.007)$ & -0.001 & $(0.006)$ & -0.005 & $(0.006)$ & -0.003 & $(0.008)$ & -0.001 & $(0.006)$ \\
\hline IC Lag t-6 & -0.006 & $(0.007)$ & -0.003 & $(0.007)$ & -0.003 & $(0.005)$ & -0.006 & $(0.006)$ & -0.006 & $(0.007)$ & -0.003 & $(0.005)$ \\
\hline Obs. & 13 & 976 & 135 & 976 & 135 & & & 976 & & 976 & & 76 \\
\hline
\end{tabular}

Notes: Huber-White robust standard errors clustered on state reported in parentheses. 
Table 4: Effects of Employment-at-Will Doctrines on LBD Plant Counts, 1978-1997

\begin{tabular}{|c|c|c|c|c|}
\hline \multirow[t]{3}{*}{ Exception } & $\begin{array}{c}\text { State FE, } \\
\text { SIC2 FE, } \\
\text { YR FE }\end{array}$ & $\begin{array}{l}\text { Col. } 1 \text { plus } \\
\text { State Trends }\end{array}$ & $\begin{array}{l}\text { Col. } 1 \text { plus } \\
\text { SIC2-YR FE }\end{array}$ & $\begin{array}{l}\text { Col. } 1 \text { plus } \\
\text { State Trends, } \\
\text { SIC2-YR FE }\end{array}$ \\
\hline & (1) & $(2)$ & (3) & (4) \\
\hline & \multicolumn{4}{|c|}{ A. LBD Mfg. Log Count of All Plants } \\
\hline $\begin{array}{l}\text { Good } \\
\text { Faith }\end{array}$ & $\begin{array}{c}0.027 \\
(0.023)\end{array}$ & $\begin{array}{c}0.026 \\
(0.013)\end{array}$ & $\begin{array}{c}0.003 \\
(0.032)\end{array}$ & $\begin{array}{c}0.020 \\
(0.026)\end{array}$ \\
\hline $\begin{array}{l}\text { Public } \\
\text { Policy }\end{array}$ & $\begin{array}{c}0.061 \\
(0.021)\end{array}$ & $\begin{array}{c}0.008 \\
(0.006)\end{array}$ & $\begin{array}{c}0.068 \\
(0.026)\end{array}$ & $\begin{array}{c}0.006 \\
(0.023)\end{array}$ \\
\hline $\begin{array}{l}\text { Implied } \\
\text { Contract }\end{array}$ & $\begin{array}{l}-0.012 \\
(0.019)\end{array}$ & $\begin{array}{l}-0.017 \\
(0.007)\end{array}$ & $\begin{array}{l}-0.019 \\
(0.025)\end{array}$ & $\begin{array}{l}-0.017 \\
(0.016)\end{array}$ \\
\hline \multirow[t]{2}{*}{ Obs. } & 3,911 & 3,911 & 3,911 & 3,911 \\
\hline & \multicolumn{4}{|c|}{ B. LBD Mfg. Log Count of Continuing Plants } \\
\hline $\begin{array}{l}\text { Good } \\
\text { Faith }\end{array}$ & $\begin{array}{c}0.047 \\
(0.027)\end{array}$ & $\begin{array}{c}0.040 \\
(0.015)\end{array}$ & $\begin{array}{c}0.021 \\
(0.036)\end{array}$ & $\begin{array}{c}0.035 \\
(0.027)\end{array}$ \\
\hline $\begin{array}{l}\text { Public } \\
\text { Policy }\end{array}$ & $\begin{array}{c}0.068 \\
(0.024)\end{array}$ & $\begin{array}{c}0.008 \\
(0.007)\end{array}$ & $\begin{array}{c}0.076 \\
(0.029)\end{array}$ & $\begin{array}{c}0.007 \\
(0.024)\end{array}$ \\
\hline $\begin{array}{l}\text { Implied } \\
\text { Contract }\end{array}$ & $\begin{array}{l}-0.013 \\
(0.022)\end{array}$ & $\begin{array}{l}-0.015 \\
(0.008)\end{array}$ & $\begin{array}{l}-0.021 \\
(0.027)\end{array}$ & $\begin{array}{l}-0.015 \\
(0.017)\end{array}$ \\
\hline \multirow[t]{2}{*}{ Obs. } & 3,891 & 3,891 & 3,891 & 3,891 \\
\hline & \multicolumn{4}{|c|}{ C. LBD Mfg. Log Count of Entering Plants } \\
\hline $\begin{array}{l}\text { Good } \\
\text { Faith }\end{array}$ & $\begin{array}{l}-0.117 \\
(0.031)\end{array}$ & $\begin{array}{l}-0.068 \\
(0.028)\end{array}$ & $\begin{array}{l}-0.131 \\
(0.032)\end{array}$ & $\begin{array}{l}-0.077 \\
(0.034)\end{array}$ \\
\hline $\begin{array}{l}\text { Public } \\
\text { Policy }\end{array}$ & $\begin{array}{c}0.016 \\
(0.028)\end{array}$ & $\begin{array}{l}-0.011 \\
(0.028)\end{array}$ & $\begin{array}{c}0.015 \\
(0.030)\end{array}$ & $\begin{array}{l}-0.019 \\
(0.033)\end{array}$ \\
\hline $\begin{array}{l}\text { Implied } \\
\text { Contract }\end{array}$ & $\begin{array}{l}-0.021 \\
(0.024)\end{array}$ & $\begin{array}{l}-0.030 \\
(0.031)\end{array}$ & $\begin{array}{l}-0.016 \\
(0.028)\end{array}$ & $\begin{array}{l}-0.030 \\
(0.034)\end{array}$ \\
\hline \multirow[t]{2}{*}{ Obs. } & 3,846 & 3,846 & 3,846 & 3,846 \\
\hline & \multicolumn{4}{|c|}{ D. LBD Mfg. Log Count of Exiting Plants } \\
\hline $\begin{array}{l}\text { Good } \\
\text { Faith }\end{array}$ & $\begin{array}{c}0.011 \\
(0.026)\end{array}$ & $\begin{array}{c}0.005 \\
(0.034)\end{array}$ & $\begin{array}{l}-0.012 \\
(0.029)\end{array}$ & $\begin{array}{l}-0.002 \\
(0.043)\end{array}$ \\
\hline $\begin{array}{l}\text { Public } \\
\text { Policy }\end{array}$ & $\begin{array}{c}0.063 \\
(0.018)\end{array}$ & $\begin{array}{c}0.048 \\
(0.022)\end{array}$ & $\begin{array}{c}0.068 \\
(0.023)\end{array}$ & $\begin{array}{c}0.042 \\
(0.032)\end{array}$ \\
\hline $\begin{array}{l}\text { Implied } \\
\text { Contract }\end{array}$ & $\begin{array}{l}-0.006 \\
(0.020)\end{array}$ & $\begin{array}{l}-0.022 \\
(0.022)\end{array}$ & $\begin{array}{l}-0.009 \\
(0.023)\end{array}$ & $\begin{array}{c}-0.021 \\
(0.025)\end{array}$ \\
\hline Obs. & 3,862 & 3,862 & 3,862 & 3,862 \\
\hline
\end{tabular}

Notes: Five-year blocks. Huber-White robust standard errors clustered on stateyear reported in parentheses. 
Table 5: Effects of Employment-at-Will Doctrines on

ASM Employment Levels, 1976-1999

\begin{tabular}{|c|c|c|c|c|c|c|}
\hline \multirow[t]{2}{*}{$\begin{array}{c}\text { Legal } \\
\text { Exception }\end{array}$} & $\begin{array}{c}\text { State FE, } \\
\text { SIC2 FE, } \\
\text { YR FE }\end{array}$ & $\begin{array}{l}\text { Col. } 1 \text { plus } \\
\text { State Trends }\end{array}$ & $\begin{array}{l}\text { Col. } 1 \text { plus } \\
\text { SIC2-YR FE }\end{array}$ & $\begin{array}{l}\text { Col. } 1 \text { plus } \\
\text { State Trends, } \\
\text { SIC2-YR FE }\end{array}$ & $\begin{array}{l}\text { Plant FE, } \\
\text { YR FE }\end{array}$ & $\begin{array}{c}\text { Col. } 5 \text { plus } \\
\text { State Trends, } \\
\text { SIC2-YR FE }\end{array}$ \\
\hline & (1) & $(2)$ & (3) & (4) & (5) & (6) \\
\hline & \multicolumn{6}{|c|}{ A. ASM Log Total Employment } \\
\hline $\begin{array}{l}\text { Good } \\
\text { Faith }\end{array}$ & $\begin{array}{c}0.025 \\
(0.033)\end{array}$ & $\begin{array}{c}0.079 \\
(0.036)\end{array}$ & $\begin{array}{c}0.015 \\
(0.030)\end{array}$ & $\begin{array}{c}0.068 \\
(0.032)\end{array}$ & $\begin{array}{c}0.033 \\
(0.031)\end{array}$ & $\begin{array}{c}0.020 \\
(0.025)\end{array}$ \\
\hline $\begin{array}{l}\text { Public } \\
\text { Policy }\end{array}$ & $\begin{array}{c}0.015 \\
(0.016)\end{array}$ & $\begin{array}{l}-0.002 \\
(0.013)\end{array}$ & $\begin{array}{c}0.014 \\
(0.014)\end{array}$ & $\begin{array}{l}-0.001 \\
(0.012)\end{array}$ & $\begin{array}{c}0.016 \\
(0.016)\end{array}$ & $\begin{array}{c}0.010 \\
(0.013)\end{array}$ \\
\hline $\begin{array}{l}\text { Implied } \\
\text { Contract }\end{array}$ & $\begin{array}{l}-0.012 \\
(0.018)\end{array}$ & $\begin{array}{l}-0.011 \\
(0.012)\end{array}$ & $\begin{array}{l}-0.004 \\
(0.015)\end{array}$ & $\begin{array}{l}-0.005 \\
(0.011)\end{array}$ & $\begin{array}{l}-0.012 \\
(0.018)\end{array}$ & $\begin{array}{l}-0.009 \\
(0.015)\end{array}$ \\
\hline \multirow[t]{2}{*}{ Obs. } & 135,976 & 135,976 & 135,976 & 135,976 & 135,976 & 135,976 \\
\hline & \multicolumn{6}{|c|}{ B. ASM Log Production Worker Employment } \\
\hline $\begin{array}{l}\text { Good } \\
\text { Faith }\end{array}$ & $\begin{array}{l}-0.002 \\
(0.034)\end{array}$ & $\begin{array}{c}0.083 \\
(0.039)\end{array}$ & $\begin{array}{l}-0.008 \\
(0.030)\end{array}$ & $\begin{array}{c}0.070 \\
(0.034)\end{array}$ & $\begin{array}{c}0.003 \\
(0.032)\end{array}$ & $\begin{array}{l}-0.002 \\
(0.025)\end{array}$ \\
\hline $\begin{array}{l}\text { Public } \\
\text { Policy }\end{array}$ & $\begin{array}{c}0.019 \\
(0.017)\end{array}$ & $\begin{array}{c}0.000 \\
(0.013)\end{array}$ & $\begin{array}{c}0.017 \\
(0.014)\end{array}$ & $\begin{array}{c}0.000 \\
(0.012)\end{array}$ & $\begin{array}{c}0.021 \\
(0.017)\end{array}$ & $\begin{array}{c}0.014 \\
(0.013)\end{array}$ \\
\hline $\begin{array}{l}\text { Implied } \\
\text { Contract }\end{array}$ & $\begin{array}{l}-0.010 \\
(0.020)\end{array}$ & $\begin{array}{l}-0.011 \\
(0.013)\end{array}$ & $\begin{array}{c}0.001 \\
(0.016)\end{array}$ & $\begin{array}{l}-0.003 \\
(0.012)\end{array}$ & $\begin{array}{l}-0.009 \\
(0.020)\end{array}$ & $\begin{array}{l}-0.004 \\
(0.016)\end{array}$ \\
\hline \multirow[t]{2}{*}{ Obs. } & 135,932 & 135,932 & 135,932 & 135,932 & 135,932 & 135,932 \\
\hline & \multicolumn{6}{|c|}{ C. ASM Log Non-Production Worker Employment } \\
\hline $\begin{array}{l}\text { Good } \\
\text { Faith }\end{array}$ & $\begin{array}{c}0.052 \\
(0.035)\end{array}$ & $\begin{array}{c}0.079 \\
(0.026)\end{array}$ & $\begin{array}{c}0.040 \\
(0.033)\end{array}$ & $\begin{array}{c}0.071 \\
(0.025)\end{array}$ & $\begin{array}{c}0.065 \\
(0.037)\end{array}$ & $\begin{array}{c}0.048 \\
(0.035)\end{array}$ \\
\hline $\begin{array}{l}\text { Public } \\
\text { Policy }\end{array}$ & $\begin{array}{c}0.012 \\
(0.018)\end{array}$ & $\begin{array}{l}-0.009 \\
(0.013)\end{array}$ & $\begin{array}{c}0.014 \\
(0.016)\end{array}$ & $\begin{array}{l}-0.005 \\
(0.013)\end{array}$ & $\begin{array}{c}0.009 \\
(0.018)\end{array}$ & $\begin{array}{c}0.008 \\
(0.015)\end{array}$ \\
\hline $\begin{array}{l}\text { Implied } \\
\text { Contract }\end{array}$ & $\begin{array}{c}-0.014 \\
(0.017)\end{array}$ & $\begin{array}{c}-0.009 \\
(0.011)\end{array}$ & $\begin{array}{l}-0.008 \\
(0.016)\end{array}$ & $\begin{array}{l}-0.005 \\
(0.011)\end{array}$ & $\begin{array}{c}-0.018 \\
(0.018)\end{array}$ & $\begin{array}{c}-0.012 \\
(0.015)\end{array}$ \\
\hline Obs. & 135,232 & 135,232 & 135,232 & 135,232 & 135,232 & 135,232 \\
\hline
\end{tabular}

Notes: Huber-White robust standard errors clustered on state reported in parentheses. 
Table 6: Effects of Employment-at-Will Doctrines on LBD Employment Levels, 1978-1997

\begin{tabular}{|c|c|c|c|c|}
\hline \multirow[t]{2}{*}{$\begin{array}{c}\text { Legal } \\
\text { Exception }\end{array}$} & $\begin{array}{c}\text { State FE, } \\
\text { SIC2 FE, } \\
\text { YR FE }\end{array}$ & $\begin{array}{l}\text { Col. } 1 \text { plus } \\
\text { State Trends }\end{array}$ & $\begin{array}{l}\text { Col. } 1 \text { plus } \\
\text { SIC2-YR FE }\end{array}$ & $\begin{array}{l}\text { Col. } 1 \text { plus } \\
\text { State Trends, } \\
\text { SIC2-YR FE }\end{array}$ \\
\hline & (1) & $(2)$ & (3) & (4) \\
\hline & \multicolumn{4}{|c|}{ A. LBD Mfg. Log Empl. in All Plants } \\
\hline $\begin{array}{l}\text { Good } \\
\text { Faith }\end{array}$ & $\begin{array}{c}0.061 \\
(0.044)\end{array}$ & $\begin{array}{c}0.092 \\
(0.028)\end{array}$ & $\begin{array}{c}0.045 \\
(0.053)\end{array}$ & $\begin{array}{c}0.078 \\
(0.044)\end{array}$ \\
\hline $\begin{array}{l}\text { Public } \\
\text { Policy }\end{array}$ & $\begin{array}{c}0.066 \\
(0.025)\end{array}$ & $\begin{array}{c}0.015 \\
(0.016)\end{array}$ & $\begin{array}{c}0.064 \\
(0.031)\end{array}$ & $\begin{array}{c}0.011 \\
(0.032)\end{array}$ \\
\hline $\begin{array}{l}\text { Implied } \\
\text { Contract }\end{array}$ & $\begin{array}{l}-0.027 \\
(0.028)\end{array}$ & $\begin{array}{l}-0.009 \\
(0.018)\end{array}$ & $\begin{array}{l}-0.032 \\
(0.033)\end{array}$ & $\begin{array}{l}-0.012 \\
(0.027)\end{array}$ \\
\hline \multirow[t]{2}{*}{ Obs. } & 3,911 & 3,911 & 3,911 & 3,911 \\
\hline & \multicolumn{4}{|c|}{ B. LBD Mfg. Log Empl. in Continuing Plants } \\
\hline $\begin{array}{l}\text { Good } \\
\text { Faith }\end{array}$ & $\begin{array}{c}0.067 \\
(0.045)\end{array}$ & $\begin{array}{c}0.096 \\
(0.029)\end{array}$ & $\begin{array}{c}0.051 \\
(0.054)\end{array}$ & $\begin{array}{c}0.083 \\
(0.044)\end{array}$ \\
\hline $\begin{array}{l}\text { Public } \\
\text { Policy }\end{array}$ & $\begin{array}{c}0.067 \\
(0.026)\end{array}$ & $\begin{array}{c}0.008 \\
(0.016)\end{array}$ & $\begin{array}{c}0.065 \\
(0.032)\end{array}$ & $\begin{array}{c}0.005 \\
(0.032)\end{array}$ \\
\hline $\begin{array}{l}\text { Implied } \\
\text { Contract }\end{array}$ & $\begin{array}{l}-0.030 \\
(0.028)\end{array}$ & $\begin{array}{l}-0.015 \\
(0.018)\end{array}$ & $\begin{array}{l}-0.034 \\
(0.033)\end{array}$ & $\begin{array}{l}-0.017 \\
(0.028)\end{array}$ \\
\hline \multirow[t]{2}{*}{ Obs. } & 3,891 & 3,891 & 3,891 & 3,891 \\
\hline & \multicolumn{4}{|c|}{ C. LBD Mfg. Log Empl. in Entering Plants } \\
\hline $\begin{array}{l}\text { Good } \\
\text { Faith }\end{array}$ & $\begin{array}{l}-0.004 \\
(0.048)\end{array}$ & $\begin{array}{c}0.014 \\
(0.056)\end{array}$ & $\begin{array}{c}-0.023 \\
(0.053)\end{array}$ & $\begin{array}{l}-0.001 \\
(0.068)\end{array}$ \\
\hline $\begin{array}{l}\text { Public } \\
\text { Policy }\end{array}$ & $\begin{array}{c}0.035 \\
(0.046)\end{array}$ & $\begin{array}{c}0.127 \\
(0.047)\end{array}$ & $\begin{array}{c}0.029 \\
(0.047)\end{array}$ & $\begin{array}{c}0.106 \\
(0.052)\end{array}$ \\
\hline $\begin{array}{l}\text { Implied } \\
\text { Contract }\end{array}$ & $\begin{array}{c}0.021 \\
(0.045)\end{array}$ & $\begin{array}{c}0.123 \\
(0.058)\end{array}$ & $\begin{array}{c}0.020 \\
(0.046)\end{array}$ & $\begin{array}{c}0.113 \\
(0.056)\end{array}$ \\
\hline \multirow[t]{2}{*}{ Obs. } & 3,846 & 3,846 & 3,846 & 3,846 \\
\hline & \multicolumn{4}{|c|}{ D. LBD Mfg. Log Empl. in Exiting Plants } \\
\hline $\begin{array}{l}\text { Good } \\
\text { Faith }\end{array}$ & $\begin{array}{c}0.073 \\
(0.048)\end{array}$ & $\begin{array}{c}0.075 \\
(0.093)\end{array}$ & $\begin{array}{c}0.048 \\
(0.056)\end{array}$ & $\begin{array}{c}0.066 \\
(0.112)\end{array}$ \\
\hline $\begin{array}{l}\text { Public } \\
\text { Policy }\end{array}$ & $\begin{array}{c}0.080 \\
(0.038)\end{array}$ & $\begin{array}{c}0.140 \\
(0.050)\end{array}$ & $\begin{array}{c}0.070 \\
(0.040)\end{array}$ & $\begin{array}{c}0.111 \\
(0.056)\end{array}$ \\
\hline $\begin{array}{l}\text { Implied } \\
\text { Contract }\end{array}$ & $\begin{array}{c}0.019 \\
(0.040)\end{array}$ & $\begin{array}{c}0.133 \\
(0.044)\end{array}$ & $\begin{array}{c}0.016 \\
(0.044)\end{array}$ & $\begin{array}{c}0.124 \\
(0.045)\end{array}$ \\
\hline Obs. & 3,862 & 3,862 & 3,862 & 3,862 \\
\hline
\end{tabular}

Notes: Five-year blocks. Huber-White robust standard errors clustered on stateyear reported in parentheses. 
Table 7: Effects of Employment-at-Will Doctrines on ASM Capital Investment, 1976-1999

\begin{tabular}{|c|c|c|c|c|c|c|}
\hline \multirow[t]{2}{*}{$\begin{array}{c}\text { Legal } \\
\text { Exception }\end{array}$} & $\begin{array}{l}\text { State FE, } \\
\text { SIC2 FE, } \\
\text { YR FE }\end{array}$ & $\begin{array}{l}\text { Col. } 1 \text { plus } \\
\text { State Trends }\end{array}$ & $\begin{array}{l}\text { Col. } 1 \text { plus } \\
\text { SIC2-YR FE }\end{array}$ & $\begin{array}{l}\text { Col. } 1 \text { plus } \\
\text { State Trends, } \\
\text { SIC2-YR FE }\end{array}$ & $\begin{array}{l}\text { Plant FE, } \\
\text { YR FE }\end{array}$ & $\begin{array}{l}\text { Col. } 5 \text { plus } \\
\text { State Trends, } \\
\text { SIC2-YR FE }\end{array}$ \\
\hline & (1) & $(2)$ & (3) & (4) & (5) & (6) \\
\hline & \multicolumn{6}{|c|}{ A. ASM Log Total Capital Investment } \\
\hline $\begin{array}{l}\text { Good } \\
\text { Faith }\end{array}$ & $\begin{array}{c}0.087 \\
(0.037)\end{array}$ & $\begin{array}{c}0.146 \\
(0.057)\end{array}$ & $\begin{array}{c}0.059 \\
(0.034)\end{array}$ & $\begin{array}{c}0.122 \\
(0.050)\end{array}$ & $\begin{array}{c}0.092 \\
(0.035)\end{array}$ & $\begin{array}{c}0.065 \\
(0.031)\end{array}$ \\
\hline $\begin{array}{l}\text { Public } \\
\text { Policy }\end{array}$ & $\begin{array}{c}0.019 \\
(0.025)\end{array}$ & $\begin{array}{c}0.001 \\
(0.027)\end{array}$ & $\begin{array}{c}0.023 \\
(0.025)\end{array}$ & $\begin{array}{c}0.005 \\
(0.024)\end{array}$ & $\begin{array}{c}0.022 \\
(0.025)\end{array}$ & $\begin{array}{c}0.024 \\
(0.025)\end{array}$ \\
\hline $\begin{array}{l}\text { Implied } \\
\text { Contract }\end{array}$ & $\begin{array}{c}0.012 \\
(0.020)\end{array}$ & $\begin{array}{l}-0.002 \\
(0.024)\end{array}$ & $\begin{array}{c}0.011 \\
(0.020)\end{array}$ & $\begin{array}{c}0.003 \\
(0.021)\end{array}$ & $\begin{array}{c}0.009 \\
(0.021)\end{array}$ & $\begin{array}{c}0.005 \\
(0.022)\end{array}$ \\
\hline \multirow[t]{2}{*}{ Obs. } & 133,608 & 133,608 & 133,608 & 133,608 & 133,608 & 133,608 \\
\hline & \multicolumn{6}{|c|}{ B. ASM Log Total Capital-Labor Ratio } \\
\hline $\begin{array}{l}\text { Good } \\
\text { Faith }\end{array}$ & $\begin{array}{c}0.056 \\
(0.027)\end{array}$ & $\begin{array}{l}-0.022 \\
(0.024)\end{array}$ & $\begin{array}{c}0.034 \\
(0.021)\end{array}$ & $\begin{array}{l}-0.021 \\
(0.024)\end{array}$ & $\begin{array}{c}0.045 \\
(0.026)\end{array}$ & $\begin{array}{c}0.046 \\
(0.012)\end{array}$ \\
\hline $\begin{array}{l}\text { Public } \\
\text { Policy }\end{array}$ & $\begin{array}{l}-0.028 \\
(0.019)\end{array}$ & $\begin{array}{c}0.000 \\
(0.013)\end{array}$ & $\begin{array}{l}-0.025 \\
(0.014)\end{array}$ & $\begin{array}{l}-0.003 \\
(0.011)\end{array}$ & $\begin{array}{l}-0.027 \\
(0.019)\end{array}$ & $\begin{array}{l}-0.020 \\
(0.012)\end{array}$ \\
\hline $\begin{array}{l}\text { Implied } \\
\text { Contract }\end{array}$ & $\begin{array}{c}0.024 \\
(0.021)\end{array}$ & $\begin{array}{c}0.016 \\
(0.011)\end{array}$ & $\begin{array}{c}0.011 \\
(0.015)\end{array}$ & $\begin{array}{c}0.008 \\
(0.010)\end{array}$ & $\begin{array}{c}0.020 \\
(0.021)\end{array}$ & $\begin{array}{c}0.011 \\
(0.014)\end{array}$ \\
\hline Obs. & 119,181 & 119,181 & 119,181 & 119,181 & 119,181 & 119,181 \\
\hline
\end{tabular}

Notes: Huber-White robust standard errors clustered on state reported in parentheses. 
Table 8: Effects of Employment-at-Will Doctrines on ASM Labor Productivity and Total Factor Productivity, 1976-1999

\begin{tabular}{lcccccc}
\hline \multirow{2}{*}{$\begin{array}{l}\text { Legal } \\
\text { Exception }\end{array}$} & $\begin{array}{c}\text { State FE, } \\
\text { SIC2 FE, } \\
\text { YR FE }\end{array}$ & $\begin{array}{c}\text { Col. 1 plus } \\
\text { State Trends }\end{array}$ & $\begin{array}{c}\text { Col. 1 plus } \\
\text { SIC2-YR FE }\end{array}$ & $\begin{array}{c}\text { Col. 1 plus } \\
\text { State Trends, } \\
\text { SIC2-YR FE }\end{array}$ & $\begin{array}{c}\text { Plant FE, } \\
\text { YR FE }\end{array}$ & $\begin{array}{c}\text { Col. 5 plus } \\
\text { State Trends, } \\
\text { SIC2-YR FE }\end{array}$ \\
\cline { 2 - 6 } & $(1)$ & $(2)$ & $(3)$ & $(4)$ & $(5)$ & $(6)$ \\
Good & -0.019 & -0.023 & -0.017 & -0.022 & -0.020 & -0.014 \\
Faith & $(0.014)$ & $(0.009)$ & $(0.014)$ & $(0.009)$ & $(0.015)$ & $(0.008)$ \\
Public & 0.006 & 0.004 & 0.005 & 0.004 & 0.004 & 0.002 \\
Policy & $(0.008)$ & $(0.007)$ & $(0.008)$ & $(0.007)$ & $(0.009)$ & $(0.008)$ \\
Implied & -0.005 & -0.003 & -0.005 & -0.003 & -0.004 & -0.006 \\
Contract & $(0.008)$ & $(0.008)$ & $(0.008)$ & $(0.008)$ & $(0.008)$ & $(0.007)$ \\
Obs. & 110,881 & 110,881 & 110,881 & 110,881 & 110,881 & 110,881 \\
& & & B. ASM Log Labor Productivity & & \\
Good & 0.050 & -0.004 & 0.051 & 0.002 & 0.039 & 0.044 \\
Faith & $(0.018)$ & $(0.008)$ & $(0.015)$ & $(0.008)$ & $(0.017)$ & $(0.011)$ \\
Public & -0.004 & 0.004 & -0.008 & 0.005 & -0.003 & -0.008 \\
Policy & $(0.010)$ & $(0.005)$ & $(0.009)$ & $(0.006)$ & $(0.011)$ & $(0.009)$ \\
Implied & 0.001 & 0.005 & 0.001 & 0.006 & -0.002 & -0.002 \\
Contract & $(0.011)$ & $(0.007)$ & $(0.010)$ & $(0.007)$ & $(0.011)$ & $(0.009)$ \\
Obs. & 135,972 & 135,972 & 135,972 & 135,972 & 135,972 & 135,972 \\
\hline
\end{tabular}

Notes: Huber-White robust standard errors clustered on state reported in parentheses. TFP is the establishment-level residual from a regression of value-added on four factors of production (production employment, non-production employment, machinery capital and structures capital) at the industry-year level. 
App. Table 1: Dynamic Effects of Employment-at-Will Doctrines on LBD Manufacturing Absolute Annual Employment Changes, 1976-1999

\begin{tabular}{|c|c|c|c|c|c|c|c|c|}
\hline \multirow{3}{*}{$\begin{array}{c}\text { Legal } \\
\text { Exception }\end{array}$} & \multicolumn{2}{|c|}{$\begin{array}{l}\text { State FE, } \\
\text { SIC2 FE, } \\
\text { YR FE }\end{array}$} & \multicolumn{2}{|c|}{$\begin{array}{l}\text { Col. } 1 \text { plus } \\
\text { State Trends }\end{array}$} & \multicolumn{2}{|c|}{$\begin{array}{l}\text { Col. } 1 \text { plus } \\
\text { SIC2-YR FE }\end{array}$} & \multicolumn{2}{|c|}{$\begin{array}{l}\text { Col. } 1 \text { plus } \\
\text { State Trends, } \\
\text { SIC2-YR FE }\end{array}$} \\
\hline & \multicolumn{2}{|c|}{ (1) } & \multicolumn{2}{|c|}{ (2) } & \multicolumn{2}{|c|}{ (3) } & \multicolumn{2}{|c|}{ (4) } \\
\hline & 0.009 & $(0.010)$ & 0.008 & $(0.011)$ & 0.008 & (0.009) & 0.007 & $(0.010)$ \\
\hline$\Delta \mathrm{GF} \mathrm{t+1}$ & 0.017 & $(0.010)$ & 0.016 & $(0.011)$ & 0.017 & $(0.009)$ & 0.016 & $(0.010)$ \\
\hline$\Delta \mathrm{GF}$ & 0.003 & $(0.009)$ & 0.003 & $(0.010)$ & 0.002 & $(0.009)$ & 0.002 & $(0.010)$ \\
\hline$\Delta \mathrm{GF}$ t-1 & -0.007 & $(0.009)$ & -0.009 & $(0.010)$ & -0.005 & $(0.008)$ & -0.006 & $(0.010)$ \\
\hline$\Delta \mathrm{GF} \mathrm{t}-2$ & -0.004 & $(0.010)$ & -0.005 & $(0.011)$ & -0.002 & $(0.009)$ & -0.003 & $(0.010)$ \\
\hline$\Delta \mathrm{GF}$ t-3 & -0.026 & $(0.011)$ & -0.027 & $(0.014)$ & -0.021 & $(0.011)$ & -0.023 & $(0.012)$ \\
\hline$\Delta \mathrm{GF} \mathrm{t}-4$ & -0.006 & $(0.011)$ & -0.007 & $(0.013)$ & -0.005 & $(0.011)$ & -0.007 & $(0.012)$ \\
\hline$\Delta \mathrm{GF} \mathrm{t}-5$ & -0.011 & $(0.008)$ & -0.012 & (0.009) & -0.006 & $(0.008)$ & -0.008 & $(0.008)$ \\
\hline GF Lag t-6 & -0.002 & $(0.008)$ & -0.006 & $(0.010)$ & 0.000 & $(0.007)$ & -0.006 & $(0.009)$ \\
\hline$\Delta \mathrm{PP} t+2$ & -0.002 & $(0.006)$ & 0.004 & $(0.006)$ & -0.006 & $(0.005)$ & 0.001 & $(0.005)$ \\
\hline$\Delta \mathrm{PP} \mathrm{t}+1$ & 0.005 & $(0.007)$ & 0.013 & $(0.008)$ & 0.003 & $(0.007)$ & 0.012 & $(0.008)$ \\
\hline$\Delta \mathrm{PP}$ & 0.003 & $(0.005)$ & 0.013 & $(0.006)$ & -0.001 & $(0.005)$ & 0.010 & $(0.006)$ \\
\hline$\Delta \mathrm{PP} \mathrm{t}-1$ & 0.009 & $(0.005)$ & 0.020 & $(0.005)$ & 0.008 & $(0.004)$ & 0.021 & $(0.005)$ \\
\hline$\Delta \mathrm{PP} \mathrm{t}-2$ & 0.007 & $(0.005)$ & 0.020 & $(0.007)$ & 0.004 & $(0.005)$ & 0.019 & $(0.007)$ \\
\hline$\Delta \mathrm{PP} \mathrm{t}-3$ & 0.007 & $(0.006)$ & 0.022 & $(0.007)$ & 0.004 & $(0.005)$ & 0.021 & $(0.006)$ \\
\hline$\Delta \mathrm{PP} \mathrm{t}-4$ & 0.012 & $(0.008)$ & 0.029 & $(0.008)$ & 0.010 & $(0.007)$ & 0.028 & $(0.008)$ \\
\hline$\Delta \mathrm{PP} \mathrm{t}-5$ & 0.011 & $(0.005)$ & 0.029 & $(0.007)$ & 0.008 & $(0.004)$ & 0.028 & $(0.006)$ \\
\hline PP Lag t-6 & 0.012 & $(0.004)$ & 0.037 & $(0.007)$ & 0.009 & $(0.003)$ & 0.034 & $(0.007)$ \\
\hline$\Delta \mathrm{IC} \mathrm{t}+2$ & 0.005 & $(0.006)$ & 0.005 & $(0.006)$ & 0.005 & $(0.006)$ & 0.005 & $(0.006)$ \\
\hline$\Delta \mathrm{IC} \mathrm{t}+1$ & 0.005 & $(0.005)$ & 0.005 & $(0.006)$ & 0.006 & $(0.006)$ & 0.006 & $(0.006)$ \\
\hline$\Delta \mathrm{IC}$ & 0.008 & $(0.008)$ & 0.007 & $(0.007)$ & 0.007 & $(0.007)$ & 0.007 & $(0.006)$ \\
\hline$\Delta \mathrm{IC} \mathrm{t}-1$ & 0.004 & $(0.006)$ & 0.002 & $(0.005)$ & 0.007 & $(0.006)$ & 0.004 & $(0.005)$ \\
\hline$\Delta \mathrm{IC} \mathrm{t}-2$ & 0.011 & $(0.005)$ & 0.009 & $(0.005)$ & 0.014 & $(0.005)$ & 0.013 & $(0.004)$ \\
\hline$\Delta \mathrm{IC} \mathrm{t}-3$ & 0.006 & $(0.006)$ & 0.005 & $(0.007)$ & 0.005 & $(0.006)$ & 0.005 & $(0.007)$ \\
\hline$\Delta \mathrm{IC} \mathrm{t}-4$ & 0.006 & $(0.005)$ & 0.005 & $(0.006)$ & 0.006 & $(0.005)$ & 0.006 & $(0.006)$ \\
\hline$\Delta \mathrm{IC} \mathrm{t}-5$ & -0.001 & $(0.005)$ & -0.001 & $(0.009)$ & 0.001 & $(0.005)$ & 0.002 & $(0.008)$ \\
\hline IC Lag t-6 & -0.001 & $(0.005)$ & 0.000 & $(0.009)$ & 0.001 & $(0.005)$ & 0.003 & $(0.009)$ \\
\hline Obs. & & 418 & & 18 & & 418 & & 418 \\
\hline
\end{tabular}

Notes: Huber-White robust standard errors clustered on state reported in parentheses. 
App. Table 2: Dynamic Effects of Employment-at-Will Doctrines on

ASM Log Employment Levels, 1976-1999

\begin{tabular}{|c|c|c|c|c|c|c|c|c|c|c|c|c|}
\hline \multirow{3}{*}{$\begin{array}{c}\text { Legal } \\
\text { Exception } \\
\Delta \text { GF t+2 }\end{array}$} & \multicolumn{2}{|c|}{$\begin{array}{c}\text { State FE, } \\
\text { SIC2 FE, } \\
\text { YR FE }\end{array}$} & \multicolumn{2}{|c|}{$\begin{array}{l}\text { Col. } 1 \text { plus } \\
\text { State Trends }\end{array}$} & \multicolumn{2}{|c|}{$\begin{array}{l}\text { Col. } 1 \text { plus } \\
\text { SIC2-YR FE }\end{array}$} & \multicolumn{2}{|c|}{$\begin{array}{l}\text { Col. } 1 \text { plus } \\
\text { State Trends, } \\
\text { SIC2-YR FE }\end{array}$} & \multicolumn{2}{|c|}{$\begin{array}{c}\text { Plant FE, } \\
\text { YR FE }\end{array}$} & \multicolumn{2}{|c|}{$\begin{array}{c}\text { Col. } 5 \text { plus } \\
\text { State Trends, } \\
\text { SIC2-YR FE }\end{array}$} \\
\hline & \multicolumn{2}{|c|}{$(1)$} & \multicolumn{2}{|c|}{ (2) } & \multicolumn{2}{|c|}{ (3) } & \multicolumn{2}{|c|}{ (4) } & \multicolumn{2}{|c|}{$(5)$} & \multicolumn{2}{|c|}{ (6) } \\
\hline & 0.006 & $(0.021)$ & 0.013 & $(0.008)$ & 0.000 & $(0.020)$ & 0.011 & $(0.008)$ & 0.017 & $(0.021)$ & 0.003 & $(0.021)$ \\
\hline$\Delta \mathrm{GF} \mathrm{t}+1$ & 0.034 & $(0.019)$ & 0.043 & $(0.012)$ & 0.027 & (0.019) & 0.042 & $(0.010)$ & 0.039 & $(0.016)$ & 0.021 & $(0.018)$ \\
\hline$\Delta \mathrm{GF}$ & 0.061 & $(0.019)$ & 0.080 & $(0.021)$ & 0.054 & $(0.018)$ & 0.077 & $(0.017)$ & 0.068 & $(0.017)$ & 0.050 & $(0.018)$ \\
\hline$\Delta \mathrm{GF}$ t-1 & 0.068 & $(0.021)$ & 0.100 & $(0.023)$ & 0.058 & $(0.020)$ & 0.094 & $(0.018)$ & 0.077 & $(0.019)$ & 0.058 & $(0.022)$ \\
\hline$\Delta \mathrm{GF}$ t -2 & 0.068 & $(0.032)$ & 0.122 & $(0.028)$ & 0.058 & $(0.031)$ & 0.114 & $(0.023)$ & 0.078 & $(0.028)$ & 0.055 & $(0.028)$ \\
\hline$\Delta \mathrm{GF}$ t-3 & 0.093 & $(0.035)$ & 0.155 & $(0.029)$ & 0.078 & $(0.032)$ & 0.142 & $(0.024)$ & 0.105 & $(0.031)$ & 0.077 & $(0.029)$ \\
\hline$\Delta \mathrm{GF} \mathrm{t-4}$ & 0.083 & $(0.030)$ & 0.156 & $(0.026)$ & 0.066 & $(0.028)$ & 0.140 & $(0.023)$ & 0.096 & $(0.026)$ & 0.062 & $(0.026)$ \\
\hline$\Delta \mathrm{GF}$ t-5 & 0.104 & $(0.036)$ & 0.188 & $(0.029)$ & 0.084 & $(0.034)$ & 0.167 & $(0.024)$ & 0.116 & $(0.032)$ & 0.077 & $(0.034)$ \\
\hline GF Lag t-6 & 0.042 & $(0.046)$ & 0.213 & $(0.033)$ & 0.031 & $(0.042)$ & 0.189 & $(0.028)$ & 0.053 & $(0.044)$ & 0.027 & $(0.041)$ \\
\hline$\Delta \mathrm{PP} \mathrm{t}+2$ & 0.020 & $(0.016)$ & -0.006 & $(0.011)$ & 0.017 & $(0.013)$ & -0.008 & $(0.009)$ & 0.023 & $(0.016)$ & 0.014 & $(0.013)$ \\
\hline$\Delta \mathrm{PP} \mathrm{t}+1$ & 0.021 & $(0.015)$ & -0.016 & $(0.011)$ & 0.012 & $(0.012)$ & -0.024 & $(0.008)$ & 0.025 & $(0.015)$ & 0.009 & $(0.012)$ \\
\hline$\Delta \mathrm{PP}$ & 0.019 & $(0.016)$ & -0.025 & $(0.011)$ & 0.012 & $(0.013)$ & -0.029 & $(0.008)$ & 0.022 & $(0.015)$ & 0.008 & $(0.012)$ \\
\hline$\Delta \mathrm{PP}$ t- 1 & 0.021 & $(0.016)$ & -0.023 & $(0.012)$ & 0.015 & $(0.013)$ & -0.028 & $(0.010)$ & 0.025 & $(0.016)$ & 0.012 & $(0.013)$ \\
\hline$\Delta \mathrm{PP} \mathrm{t}-2$ & 0.027 & $(0.019)$ & -0.027 & $(0.016)$ & 0.019 & $(0.016)$ & -0.033 & $(0.012)$ & 0.030 & $(0.019)$ & 0.015 & $(0.015)$ \\
\hline$\Delta \mathrm{PP}$ t-3 & 0.029 & $(0.021)$ & -0.032 & $(0.018)$ & 0.022 & $(0.019)$ & -0.034 & $(0.016)$ & 0.031 & $(0.021)$ & 0.018 & $(0.018)$ \\
\hline$\Delta \mathrm{PP} \mathrm{t}-4$ & 0.028 & $(0.022)$ & -0.035 & $(0.018)$ & 0.024 & (0.019) & -0.035 & $(0.016)$ & 0.030 & $(0.022)$ & 0.018 & $(0.018)$ \\
\hline$\Delta \mathrm{PP} \mathrm{t}-5$ & 0.031 & $(0.023)$ & -0.034 & $(0.019)$ & 0.027 & $(0.021)$ & -0.034 & $(0.017)$ & 0.033 & $(0.023)$ & 0.021 & $(0.020)$ \\
\hline PP Lag t-6 & 0.029 & $(0.033)$ & -0.048 & $(0.020)$ & 0.024 & $(0.030)$ & -0.047 & $(0.018)$ & 0.031 & $(0.032)$ & 0.017 & $(0.028)$ \\
\hline$\Delta \mathrm{IC} \mathrm{t}+2$ & -0.007 & $(0.011)$ & -0.003 & $(0.009)$ & -0.003 & $(0.010)$ & -0.002 & $(0.008)$ & -0.005 & $(0.011)$ & -0.003 & $(0.010)$ \\
\hline$\Delta \mathrm{IC} \mathrm{t}+1$ & -0.017 & $(0.015)$ & -0.010 & $(0.013)$ & -0.012 & $(0.013)$ & -0.009 & $(0.011)$ & -0.014 & $(0.015)$ & -0.009 & $(0.013)$ \\
\hline$\Delta \mathrm{IC}$ & -0.023 & $(0.017)$ & -0.014 & $(0.017)$ & -0.017 & $(0.016)$ & -0.012 & $(0.015)$ & -0.021 & $(0.017)$ & -0.015 & $(0.015)$ \\
\hline$\Delta \mathrm{IC} \mathrm{t}-1$ & -0.025 & $(0.023)$ & -0.015 & $(0.020)$ & -0.014 & $(0.020)$ & -0.008 & $(0.017)$ & -0.023 & $(0.022)$ & -0.014 & $(0.019)$ \\
\hline$\Delta \mathrm{IC} \mathrm{t}-2$ & -0.019 & $(0.023)$ & -0.009 & $(0.022)$ & -0.008 & $(0.022)$ & -0.003 & $(0.020)$ & -0.017 & $(0.023)$ & -0.009 & $(0.020)$ \\
\hline$\Delta \mathrm{IC} \mathrm{t}-3$ & -0.014 & $(0.025)$ & -0.002 & $(0.024)$ & -0.002 & $(0.023)$ & 0.006 & $(0.021)$ & -0.013 & $(0.025)$ & -0.004 & $(0.022)$ \\
\hline$\Delta \mathrm{IC} \mathrm{t}-4$ & -0.016 & $(0.028)$ & -0.001 & $(0.026)$ & -0.004 & $(0.025)$ & 0.007 & $(0.023)$ & -0.013 & $(0.027)$ & -0.006 & $(0.023)$ \\
\hline$\Delta \mathrm{IC} \mathrm{t}-5$ & -0.016 & $(0.028)$ & 0.000 & $(0.027)$ & -0.005 & $(0.026)$ & 0.007 & $(0.025)$ & -0.012 & $(0.027)$ & -0.007 & $(0.024)$ \\
\hline IC Lag t-6 & -0.016 & $(0.033)$ & 0.001 & $(0.032)$ & -0.006 & $(0.030)$ & 0.008 & $(0.030)$ & -0.013 & $(0.032)$ & -0.011 & $(0.029)$ \\
\hline Obs. & 135 & 976 & 13 & 76 & & 76 & & 976 & 1 & 76 & & 76 \\
\hline
\end{tabular}

Notes: Huber-White robust standard errors clustered on state reported in parentheses. 
App. Table 3: Dynamic Effects of Employment-at-Will Doctrines on

LBD Log Manufacturing Employment Levels, 1976-1999

\begin{tabular}{|c|c|c|c|c|c|c|c|c|}
\hline \multirow{3}{*}{$\begin{array}{c}\text { Legal } \\
\text { Exception } \\
\Delta \text { GF t+2 }\end{array}$} & \multicolumn{2}{|c|}{$\begin{array}{l}\text { State FE, } \\
\text { SIC2 FE, } \\
\text { YR FE }\end{array}$} & \multicolumn{2}{|c|}{$\begin{array}{l}\text { Col. } 1 \text { plus } \\
\text { State Trends }\end{array}$} & \multicolumn{2}{|c|}{$\begin{array}{l}\text { Col. } 1 \text { plus } \\
\text { SIC2-YR FE }\end{array}$} & \multicolumn{2}{|c|}{$\begin{array}{l}\text { Col. } 1 \text { plus } \\
\text { State Trends, } \\
\text { SIC2-YR FE }\end{array}$} \\
\hline & \multicolumn{2}{|c|}{ (1) } & \multicolumn{2}{|c|}{ (2) } & \multicolumn{2}{|c|}{ (3) } & \multicolumn{2}{|c|}{ (4) } \\
\hline & 0.011 & $(0.036)$ & 0.046 & $(0.018)$ & 0.002 & $(0.038)$ & 0.037 & $(0.016)$ \\
\hline$\Delta \mathrm{GF} \mathrm{t}+1$ & 0.078 & $(0.054)$ & 0.070 & $(0.018)$ & 0.069 & $(0.056)$ & 0.060 & $(0.018)$ \\
\hline$\Delta \mathrm{GF}$ & 0.129 & $(0.052)$ & 0.128 & $(0.024)$ & 0.115 & $(0.055)$ & 0.114 & $(0.024)$ \\
\hline$\Delta \mathrm{GF} \mathrm{t}-1$ & 0.108 & $(0.053)$ & 0.132 & $(0.027)$ & 0.087 & $(0.056)$ & 0.113 & $(0.028)$ \\
\hline$\Delta \mathrm{GF} \mathrm{t}-2$ & 0.153 & $(0.062)$ & 0.182 & $(0.031)$ & 0.132 & $(0.065)$ & 0.162 & $(0.033)$ \\
\hline$\Delta \mathrm{GF} t-3$ & 0.169 & $(0.068)$ & 0.197 & $(0.036)$ & 0.133 & $(0.070)$ & 0.162 & $(0.040)$ \\
\hline$\Delta \mathrm{GF} \mathrm{t}-4$ & 0.178 & $(0.072)$ & 0.211 & $(0.036)$ & 0.142 & $(0.077)$ & 0.179 & $(0.038)$ \\
\hline$\Delta \mathrm{GF} \mathrm{t}-5$ & 0.205 & $(0.071)$ & 0.248 & $(0.042)$ & 0.162 & $(0.076)$ & 0.209 & $(0.047)$ \\
\hline GF Lag t-6 & 0.154 & $(0.104)$ & 0.264 & $(0.052)$ & 0.106 & $(0.107)$ & 0.225 & $(0.053)$ \\
\hline$\Delta \mathrm{PP} t+2$ & 0.079 & $(0.034)$ & -0.012 & $(0.022)$ & 0.088 & $(0.035)$ & -0.010 & $(0.019)$ \\
\hline$\Delta \mathrm{PP} t+1$ & 0.096 & $(0.028)$ & -0.012 & $(0.019)$ & 0.099 & $(0.028)$ & -0.016 & $(0.015)$ \\
\hline$\Delta \mathrm{PP}$ & 0.100 & $(0.028)$ & -0.021 & $(0.021)$ & 0.105 & $(0.030)$ & -0.023 & $(0.017)$ \\
\hline$\Delta \mathrm{PP}$ t-1 & 0.098 & $(0.033)$ & -0.031 & $(0.026)$ & 0.102 & $(0.034)$ & -0.037 & $(0.023)$ \\
\hline$\Delta \mathrm{PP} \mathrm{t}-2$ & 0.111 & $(0.045)$ & -0.046 & $(0.034)$ & 0.111 & $(0.044)$ & -0.055 & $(0.029)$ \\
\hline$\Delta \mathrm{PP} \mathrm{t}-3$ & 0.125 & $(0.044)$ & -0.041 & $(0.037)$ & 0.125 & $(0.045)$ & -0.049 & $(0.032)$ \\
\hline$\Delta \mathrm{PP} \mathrm{t}-4$ & 0.130 & $(0.046)$ & -0.043 & $(0.039)$ & 0.133 & $(0.048)$ & -0.045 & $(0.033)$ \\
\hline$\Delta \mathrm{PP} \mathrm{t}-5$ & 0.125 & $(0.050)$ & -0.057 & $(0.044)$ & 0.128 & $(0.053)$ & -0.061 & $(0.039)$ \\
\hline PP Lag t-6 & 0.117 & $(0.071)$ & -0.094 & $(0.049)$ & 0.121 & $(0.079)$ & -0.096 & $(0.043)$ \\
\hline$\Delta \mathrm{IC} \mathrm{t}+2$ & -0.012 & $(0.023)$ & -0.003 & $(0.014)$ & -0.018 & $(0.026)$ & -0.009 & $(0.013)$ \\
\hline$\Delta \mathrm{IC} \mathrm{t}+1$ & -0.037 & $(0.032)$ & -0.024 & $(0.019)$ & -0.042 & $(0.034)$ & -0.029 & $(0.017)$ \\
\hline$\Delta \mathrm{IC}$ & -0.049 & $(0.037)$ & -0.033 & $(0.025)$ & -0.056 & $(0.041)$ & -0.038 & $(0.022)$ \\
\hline$\Delta \mathrm{IC} \mathrm{t}-1$ & -0.034 & $(0.053)$ & -0.016 & $(0.035)$ & -0.041 & $(0.060)$ & -0.022 & $(0.030)$ \\
\hline$\Delta \mathrm{IC} \mathrm{t}-2$ & -0.045 & $(0.056)$ & -0.022 & $(0.041)$ & -0.052 & $(0.062)$ & -0.028 & $(0.036)$ \\
\hline$\Delta \mathrm{IC} \mathrm{t}-3$ & -0.056 & $(0.060)$ & -0.034 & $(0.044)$ & -0.063 & $(0.066)$ & -0.039 & $(0.040)$ \\
\hline$\Delta \mathrm{IC} \mathrm{t}-4$ & -0.060 & $(0.065)$ & -0.027 & $(0.048)$ & -0.070 & $(0.070)$ & -0.033 & $(0.042)$ \\
\hline$\Delta \mathrm{IC} \mathrm{t}-5$ & -0.054 & $(0.068)$ & -0.018 & $(0.049)$ & -0.069 & $(0.073)$ & -0.028 & $(0.043)$ \\
\hline IC Lag t-6 & -0.057 & $(0.087)$ & -0.033 & $(0.053)$ & -0.083 & $(0.089)$ & -0.045 & $(0.047)$ \\
\hline Obs. & \multicolumn{2}{|c|}{22,740} & \multicolumn{2}{|c|}{22,740} & \multicolumn{2}{|c|}{22,740} & \multicolumn{2}{|c|}{22,740} \\
\hline
\end{tabular}

Notes: Huber-White robust standard errors clustered on state reported in parentheses. 
App. Table 4: Dynamic Effects of Employment-at-Will Doctrines on

ASM Log Capital Investment, 1976-1999

\begin{tabular}{|c|c|c|c|c|c|c|c|c|c|c|c|c|}
\hline \multirow{3}{*}{$\begin{array}{c}\text { Legal } \\
\text { Exception } \\
\Delta \text { GF t+2 }\end{array}$} & \multicolumn{2}{|c|}{$\begin{array}{c}\text { State FE, } \\
\text { SIC2 FE, } \\
\text { YR FE }\end{array}$} & \multicolumn{2}{|c|}{$\begin{array}{l}\text { Col. } 1 \text { plus } \\
\text { State Trends }\end{array}$} & \multicolumn{2}{|c|}{$\begin{array}{l}\text { Col. } 1 \text { plus } \\
\text { SIC2-YR FE }\end{array}$} & \multicolumn{2}{|c|}{$\begin{array}{l}\text { Col. } 1 \text { plus } \\
\text { State Trends, } \\
\text { SIC2-YR FE }\end{array}$} & \multicolumn{2}{|c|}{$\begin{array}{c}\text { Plant FE, } \\
\text { YR FE }\end{array}$} & \multicolumn{2}{|c|}{$\begin{array}{c}\text { Col. } 5 \text { plus } \\
\text { State Trends, } \\
\text { SIC2-YR FE }\end{array}$} \\
\hline & \multicolumn{2}{|c|}{$(1)$} & \multicolumn{2}{|c|}{ (2) } & \multicolumn{2}{|c|}{ (3) } & \multicolumn{2}{|c|}{ (4) } & \multicolumn{2}{|c|}{$(5)$} & \multicolumn{2}{|c|}{ (6) } \\
\hline & -0.036 & $(0.070)$ & -0.008 & $(0.069)$ & -0.033 & $(0.072)$ & -0.005 & $(0.070)$ & -0.025 & $(0.071)$ & -0.019 & $(0.071)$ \\
\hline$\Delta \mathrm{GF} \mathrm{t}+1$ & -0.012 & $(0.053)$ & 0.045 & $(0.059)$ & -0.013 & $(0.047)$ & 0.039 & $(0.050)$ & -0.007 & $(0.056)$ & -0.008 & (0.049) \\
\hline$\Delta \mathrm{GF}$ & -0.046 & $(0.057)$ & 0.018 & $(0.055)$ & -0.051 & $(0.051)$ & 0.008 & $(0.045)$ & -0.051 & $(0.058)$ & -0.053 & $(0.052)$ \\
\hline$\Delta \mathrm{GF}$ t-1 & 0.001 & $(0.054)$ & 0.077 & $(0.066)$ & -0.005 & $(0.048)$ & 0.065 & $(0.056)$ & 0.007 & $(0.055)$ & 0.008 & (0.049) \\
\hline$\Delta \mathrm{GF}$ t -2 & 0.159 & $(0.088)$ & 0.250 & $(0.072)$ & 0.139 & $(0.079)$ & 0.223 & $(0.061)$ & 0.165 & $(0.084)$ & 0.148 & $(0.077)$ \\
\hline$\Delta \mathrm{GF}$ t-3 & 0.157 & $(0.082)$ & 0.256 & $(0.081)$ & 0.137 & $(0.073)$ & 0.227 & $(0.070)$ & 0.159 & $(0.082)$ & 0.143 & $(0.075)$ \\
\hline$\Delta \mathrm{GF} \mathrm{t-4}$ & 0.118 & $(0.085)$ & 0.221 & $(0.069)$ & 0.081 & $(0.080)$ & 0.175 & $(0.062)$ & 0.128 & $(0.082)$ & 0.088 & $(0.081)$ \\
\hline$\Delta \mathrm{GF}$ t-5 & 0.113 & $(0.058)$ & 0.220 & $(0.063)$ & 0.067 & $(0.054)$ & 0.166 & $(0.051)$ & 0.126 & $(0.053)$ & 0.075 & $(0.052)$ \\
\hline GF Lag t-6 & 0.082 & $(0.050)$ & 0.237 & $(0.074)$ & 0.047 & $(0.050)$ & 0.187 & $(0.060)$ & 0.086 & $(0.051)$ & 0.049 & $(0.050)$ \\
\hline$\Delta \mathrm{PP} \mathrm{t}+2$ & -0.006 & $(0.025)$ & -0.021 & $(0.024)$ & -0.018 & $(0.021)$ & -0.036 & $(0.017)$ & 0.001 & $(0.028)$ & -0.017 & $(0.020)$ \\
\hline$\Delta \mathrm{PP} \mathrm{t}+1$ & -0.004 & $(0.035)$ & -0.027 & $(0.035)$ & -0.013 & $(0.030)$ & -0.041 & $(0.026)$ & 0.002 & $(0.036)$ & -0.015 & $(0.030)$ \\
\hline$\Delta \mathrm{PP}$ & -0.036 & $(0.027)$ & -0.067 & $(0.031)$ & -0.035 & $(0.026)$ & -0.071 & $(0.027)$ & -0.026 & $(0.028)$ & -0.035 & $(0.030)$ \\
\hline$\Delta \mathrm{PP}$ t- 1 & -0.015 & $(0.036)$ & -0.052 & $(0.037)$ & -0.014 & $(0.034)$ & -0.054 & $(0.034)$ & -0.010 & $(0.037)$ & -0.017 & $(0.035)$ \\
\hline$\Delta \mathrm{PP} \mathrm{t}-2$ & -0.019 & $(0.045)$ & -0.055 & $(0.050)$ & -0.016 & $(0.043)$ & -0.059 & $(0.045)$ & -0.012 & $(0.046)$ & -0.018 & $(0.044)$ \\
\hline$\Delta \mathrm{PP}$ t-3 & -0.021 & $(0.038)$ & -0.063 & $(0.043)$ & -0.011 & $(0.037)$ & -0.061 & $(0.039)$ & -0.015 & $(0.038)$ & -0.013 & $(0.039)$ \\
\hline$\Delta \mathrm{PP} \mathrm{t}-4$ & 0.001 & $(0.039)$ & -0.045 & $(0.044)$ & 0.014 & $(0.039)$ & -0.040 & $(0.041)$ & 0.010 & $(0.039)$ & 0.013 & $(0.040)$ \\
\hline$\Delta \mathrm{PP} \mathrm{t}-5$ & -0.013 & $(0.036)$ & -0.064 & $(0.044)$ & -0.007 & $(0.038)$ & -0.064 & $(0.043)$ & -0.002 & $(0.035)$ & -0.005 & $(0.040)$ \\
\hline PP Lag t-6 & 0.008 & $(0.040)$ & -0.067 & $(0.049)$ & 0.016 & $(0.045)$ & -0.064 & $(0.045)$ & 0.016 & $(0.039)$ & 0.016 & $(0.045)$ \\
\hline$\Delta \mathrm{IC} \mathrm{t}+2$ & -0.005 & $(0.025)$ & -0.002 & $(0.025)$ & -0.005 & $(0.022)$ & 0.002 & $(0.023)$ & -0.004 & $(0.025)$ & -0.002 & $(0.022)$ \\
\hline$\Delta \mathrm{IC} \mathrm{t}+1$ & -0.017 & $(0.027)$ & -0.013 & $(0.033)$ & -0.017 & $(0.024)$ & -0.008 & $(0.030)$ & -0.013 & $(0.028)$ & -0.011 & $(0.025)$ \\
\hline$\Delta \mathrm{IC}$ & 0.003 & $(0.031)$ & 0.008 & $(0.041)$ & -0.002 & $(0.030)$ & 0.010 & $(0.039)$ & -0.002 & $(0.031)$ & -0.004 & $(0.029)$ \\
\hline$\Delta \mathrm{IC} \mathrm{t}-1$ & 0.002 & $(0.033)$ & 0.012 & $(0.047)$ & 0.006 & $(0.032)$ & 0.024 & $(0.044)$ & 0.003 & $(0.034)$ & 0.010 & $(0.032)$ \\
\hline$\Delta \mathrm{IC} \mathrm{t}-2$ & 0.009 & $(0.033)$ & 0.024 & $(0.047)$ & 0.009 & $(0.032)$ & 0.031 & $(0.041)$ & 0.006 & $(0.034)$ & 0.008 & $(0.034)$ \\
\hline$\Delta \mathrm{IC} \mathrm{t}-3$ & 0.015 & $(0.035)$ & 0.033 & $(0.052)$ & 0.009 & $(0.036)$ & 0.035 & $(0.048)$ & 0.007 & $(0.035)$ & 0.004 & $(0.038)$ \\
\hline$\Delta \mathrm{IC} \mathrm{t}-4$ & -0.021 & $(0.032)$ & 0.001 & $(0.053)$ & -0.023 & $(0.034)$ & 0.008 & $(0.050)$ & -0.025 & $(0.033)$ & -0.027 & $(0.037)$ \\
\hline$\Delta \mathrm{IC} \mathrm{t}-5$ & 0.011 & $(0.038)$ & 0.035 & $(0.057)$ & 0.008 & $(0.040)$ & 0.041 & $(0.053)$ & 0.008 & $(0.038)$ & 0.006 & $(0.041)$ \\
\hline IC Lag t-6 & 0.055 & $(0.033)$ & 0.076 & $(0.057)$ & 0.043 & $(0.036)$ & 0.078 & $(0.055)$ & 0.052 & $(0.033)$ & 0.036 & $(0.040)$ \\
\hline Obs. & 133 & 608 & 133 & 608 & 133 & & & 608 & 133 & 608 & & 608 \\
\hline
\end{tabular}

Notes: Huber-White robust standard errors clustered on state reported in parentheses. 
App. Table 5: Dynamic Effects of Employment-at-Will Doctrines on

ASM Log Capital-Labor Ratio, 1976-1999

\begin{tabular}{|c|c|c|c|c|c|c|c|c|c|c|c|c|}
\hline \multirow{3}{*}{$\begin{array}{c}\text { Legal } \\
\text { Exception } \\
\Delta \text { GF t+2 }\end{array}$} & \multicolumn{2}{|c|}{$\begin{array}{c}\text { State FE, } \\
\text { SIC2 FE, } \\
\text { YR FE }\end{array}$} & \multicolumn{2}{|c|}{$\begin{array}{l}\text { Col. } 1 \text { plus } \\
\text { State Trends }\end{array}$} & \multicolumn{2}{|c|}{$\begin{array}{l}\text { Col. } 1 \text { plus } \\
\text { SIC2-YR FE }\end{array}$} & \multicolumn{2}{|c|}{$\begin{array}{l}\text { Col. } 1 \text { plus } \\
\text { State Trends, } \\
\text { SIC2-YR FE }\end{array}$} & \multicolumn{2}{|c|}{$\begin{array}{c}\text { Plant FE, } \\
\text { YR FE }\end{array}$} & \multicolumn{2}{|c|}{$\begin{array}{l}\text { Col. } 5 \text { plus } \\
\text { State Trends, } \\
\text { SIC2-YR FE }\end{array}$} \\
\hline & \multicolumn{2}{|c|}{$(1)$} & \multicolumn{2}{|c|}{ (2) } & \multicolumn{2}{|c|}{ (3) } & \multicolumn{2}{|c|}{ (4) } & \multicolumn{2}{|c|}{$(5)$} & \multicolumn{2}{|c|}{ (6) } \\
\hline & -0.037 & $(0.029)$ & 0.001 & $(0.012)$ & -0.039 & $(0.029)$ & -0.003 & $(0.010)$ & -0.047 & $(0.028)$ & -0.029 & $(0.033)$ \\
\hline$\Delta \mathrm{GF} \mathrm{t}+1$ & -0.052 & $(0.021)$ & -0.009 & $(0.027)$ & -0.059 & $(0.021)$ & -0.019 & $(0.023)$ & -0.060 & $(0.021)$ & -0.047 & $(0.026)$ \\
\hline$\Delta \mathrm{GF}$ & -0.079 & $(0.024)$ & -0.044 & $(0.039)$ & -0.090 & $(0.023)$ & -0.056 & $(0.034)$ & -0.090 & $(0.024)$ & -0.079 & $(0.027)$ \\
\hline$\Delta \mathrm{GF}$ t-1 & -0.055 & $(0.029)$ & -0.032 & $(0.038)$ & -0.070 & $(0.029)$ & -0.045 & $(0.035)$ & -0.069 & $(0.028)$ & -0.061 & $(0.033)$ \\
\hline$\Delta \mathrm{GF}$ t -2 & -0.051 & $(0.027)$ & -0.053 & $(0.038)$ & -0.067 & $(0.026)$ & -0.063 & $(0.038)$ & -0.063 & $(0.027)$ & -0.046 & $(0.029)$ \\
\hline$\Delta \mathrm{GF}$ t-3 & -0.027 & $(0.033)$ & -0.039 & $(0.045)$ & -0.039 & $(0.032)$ & -0.045 & $(0.045)$ & -0.042 & $(0.034)$ & -0.022 & $(0.035)$ \\
\hline$\Delta \mathrm{GF} \mathrm{t-4}$ & -0.007 & $(0.036)$ & -0.033 & $(0.050)$ & -0.021 & $(0.034)$ & -0.039 & $(0.049)$ & -0.020 & $(0.036)$ & -0.002 & $(0.036)$ \\
\hline$\Delta \mathrm{GF}$ t -5 & -0.029 & $(0.035)$ & -0.066 & $(0.052)$ & -0.046 & $(0.033)$ & -0.073 & $(0.050)$ & -0.043 & $(0.036)$ & -0.024 & $(0.035)$ \\
\hline GF Lag t-6 & 0.080 & $(0.032)$ & -0.057 & $(0.050)$ & 0.036 & $(0.023)$ & -0.073 & $(0.045)$ & 0.060 & $(0.034)$ & 0.050 & $(0.022)$ \\
\hline$\Delta \mathrm{PP} \mathrm{t}+2$ & -0.024 & $(0.017)$ & 0.000 & $(0.010)$ & -0.010 & $(0.011)$ & 0.005 & $(0.008)$ & -0.025 & $(0.017)$ & -0.010 & $(0.010)$ \\
\hline$\Delta \mathrm{PP} \mathrm{t}+1$ & -0.017 & $(0.017)$ & 0.014 & $(0.011)$ & 0.000 & $(0.012)$ & 0.020 & $(0.010)$ & -0.019 & $(0.017)$ & 0.000 & $(0.011)$ \\
\hline$\Delta \mathrm{PP}$ & -0.025 & $(0.020)$ & 0.013 & $(0.015)$ & -0.012 & $(0.015)$ & 0.013 & $(0.013)$ & -0.026 & $(0.019)$ & -0.010 & $(0.014)$ \\
\hline$\Delta \mathrm{PP}$ t- 1 & -0.030 & $(0.023)$ & 0.006 & $(0.019)$ & -0.018 & $(0.018)$ & 0.006 & $(0.016)$ & -0.031 & $(0.023)$ & -0.017 & $(0.017)$ \\
\hline$\Delta \mathrm{PP} \mathrm{t}-2$ & -0.035 & $(0.026)$ & 0.013 & $(0.020)$ & -0.018 & (0.019) & 0.012 & $(0.017)$ & -0.034 & $(0.027)$ & -0.015 & $(0.018)$ \\
\hline$\Delta \mathrm{PP}$ t-3 & -0.030 & $(0.027)$ & 0.023 & $(0.021)$ & -0.015 & $(0.020)$ & 0.018 & $(0.018)$ & -0.030 & $(0.027)$ & -0.012 & $(0.018)$ \\
\hline$\Delta \mathrm{PP} \mathrm{t}-4$ & -0.036 & $(0.028)$ & 0.020 & $(0.023)$ & -0.022 & $(0.020)$ & 0.013 & $(0.019)$ & -0.036 & $(0.028)$ & -0.018 & $(0.018)$ \\
\hline$\Delta \mathrm{PP} \mathrm{t}-5$ & -0.043 & $(0.027)$ & 0.015 & $(0.023)$ & -0.028 & $(0.020)$ & 0.009 & $(0.020)$ & -0.043 & $(0.027)$ & -0.023 & $(0.018)$ \\
\hline PP Lag t-6 & -0.053 & $(0.034)$ & 0.017 & $(0.025)$ & -0.039 & $(0.025)$ & 0.004 & $(0.021)$ & -0.051 & $(0.034)$ & -0.028 & $(0.023)$ \\
\hline$\Delta \mathrm{IC} \mathrm{t}+2$ & 0.012 & $(0.017)$ & 0.014 & $(0.013)$ & 0.001 & $(0.013)$ & 0.006 & $(0.010)$ & 0.014 & $(0.017)$ & 0.006 & $(0.013)$ \\
\hline$\Delta \mathrm{IC} \mathrm{t}+1$ & 0.022 & $(0.020)$ & 0.020 & $(0.016)$ & 0.009 & $(0.015)$ & 0.013 & $(0.014)$ & 0.022 & $(0.020)$ & 0.013 & $(0.015)$ \\
\hline$\Delta \mathrm{IC}$ & 0.034 & $(0.024)$ & 0.030 & $(0.022)$ & 0.018 & $(0.018)$ & 0.020 & $(0.019)$ & 0.033 & $(0.024)$ & 0.021 & $(0.018)$ \\
\hline$\Delta \mathrm{IC} \mathrm{t}-1$ & 0.042 & $(0.027)$ & 0.035 & $(0.025)$ & 0.022 & $(0.020)$ & 0.021 & $(0.021)$ & 0.040 & $(0.027)$ & 0.024 & $(0.019)$ \\
\hline$\Delta \mathrm{IC} \mathrm{t}-2$ & 0.047 & $(0.030)$ & 0.038 & $(0.026)$ & 0.026 & $(0.022)$ & 0.022 & $(0.022)$ & 0.044 & $(0.029)$ & 0.028 & $(0.021)$ \\
\hline$\Delta \mathrm{IC} \mathrm{t}-3$ & 0.040 & $(0.031)$ & 0.029 & $(0.027)$ & 0.018 & $(0.023)$ & 0.013 & $(0.023)$ & 0.037 & $(0.031)$ & 0.019 & $(0.022)$ \\
\hline$\Delta \mathrm{IC} \mathrm{t}-4$ & 0.046 & $(0.032)$ & 0.036 & $(0.027)$ & 0.023 & $(0.022)$ & 0.020 & $(0.023)$ & 0.042 & $(0.031)$ & 0.025 & $(0.022)$ \\
\hline$\Delta \mathrm{IC} \mathrm{t}-5$ & 0.041 & $(0.033)$ & 0.029 & $(0.029)$ & 0.019 & $(0.024)$ & 0.014 & $(0.026)$ & 0.037 & $(0.033)$ & 0.021 & $(0.023)$ \\
\hline IC Lag t-6 & 0.065 & $(0.037)$ & 0.037 & $(0.033)$ & 0.036 & $(0.026)$ & 0.021 & $(0.028)$ & 0.060 & $(0.037)$ & 0.036 & $(0.026)$ \\
\hline Obs. & 11 & 181 & 119 & 181 & & & & 181 & 11 & 181 & & 181 \\
\hline
\end{tabular}

Notes: Huber-White robust standard errors clustered on state reported in parentheses. 
App. Table 6: Dynamic Effects of Employment-at-Will Doctrines on

ASM Total Factor Productivity, 1976-1999

\begin{tabular}{|c|c|c|c|c|c|c|c|c|c|c|c|c|}
\hline \multirow{3}{*}{$\begin{array}{c}\text { Legal } \\
\text { Exception } \\
\Delta \text { GF t+2 }\end{array}$} & \multicolumn{2}{|c|}{$\begin{array}{c}\text { State FE, } \\
\text { SIC2 FE, } \\
\text { YR FE }\end{array}$} & \multicolumn{2}{|c|}{$\begin{array}{l}\text { Col. } 1 \text { plus } \\
\text { State Trends }\end{array}$} & \multicolumn{2}{|c|}{$\begin{array}{l}\text { Col. } 1 \text { plus } \\
\text { SIC2-YR FE }\end{array}$} & \multicolumn{2}{|c|}{$\begin{array}{c}\text { Col. } 1 \text { plus } \\
\text { State Trends, } \\
\text { SIC2-YR FE }\end{array}$} & \multicolumn{2}{|c|}{$\begin{array}{l}\text { Plant FE, } \\
\text { YR FE }\end{array}$} & \multicolumn{2}{|c|}{$\begin{array}{l}\text { Col. } 5 \text { plus } \\
\text { State Trends, } \\
\text { SIC2-YR FE }\end{array}$} \\
\hline & \multicolumn{2}{|c|}{$(1)$} & \multicolumn{2}{|c|}{ (2) } & \multicolumn{2}{|c|}{ (3) } & \multicolumn{2}{|c|}{ (4) } & \multicolumn{2}{|c|}{$(5)$} & \multicolumn{2}{|c|}{ (6) } \\
\hline & -0.006 & $(0.020)$ & -0.010 & $(0.016)$ & -0.005 & $(0.019)$ & -0.010 & $(0.015)$ & -0.008 & $(0.019)$ & -0.008 & $(0.011)$ \\
\hline$\Delta \mathrm{GF} \mathrm{t}+1$ & -0.007 & $(0.017)$ & -0.010 & $(0.022)$ & -0.003 & $(0.016)$ & -0.008 & $(0.021)$ & -0.010 & $(0.019)$ & -0.008 & $(0.019)$ \\
\hline$\Delta \mathrm{GF}$ & -0.006 & $(0.022)$ & -0.011 & $(0.026)$ & -0.008 & $(0.020)$ & -0.014 & $(0.025)$ & -0.007 & $(0.022)$ & -0.009 & $(0.022)$ \\
\hline$\Delta \mathrm{GF} \mathrm{t}-1$ & -0.026 & $(0.020)$ & -0.032 & $(0.021)$ & -0.023 & $(0.020)$ & -0.031 & $(0.021)$ & -0.027 & $(0.022)$ & -0.027 & (0.019) \\
\hline$\Delta \mathrm{GF} \mathrm{t}-2$ & -0.016 & $(0.021)$ & -0.022 & $(0.020)$ & -0.012 & $(0.022)$ & -0.019 & $(0.020)$ & -0.019 & $(0.023)$ & -0.015 & (0.019) \\
\hline$\Delta \mathrm{GF}$ t -3 & -0.032 & $(0.018)$ & -0.040 & $(0.019)$ & -0.031 & $(0.019)$ & -0.039 & $(0.019)$ & -0.039 & $(0.020)$ & -0.037 & $(0.018)$ \\
\hline$\Delta \mathrm{GF} \mathrm{t}-4$ & -0.036 & $(0.029)$ & -0.046 & $(0.027)$ & -0.035 & $(0.029)$ & -0.046 & $(0.026)$ & -0.042 & $(0.030)$ & -0.039 & $(0.023)$ \\
\hline$\Delta \mathrm{GF} \mathrm{t}-5$ & -0.011 & $(0.031)$ & -0.022 & $(0.025)$ & -0.013 & $(0.031)$ & -0.025 & $(0.024)$ & -0.020 & $(0.033)$ & -0.019 & $(0.022)$ \\
\hline GF Lag t-6 & -0.016 & $(0.024)$ & -0.041 & $(0.022)$ & -0.014 & $(0.024)$ & -0.040 & $(0.021)$ & -0.014 & $(0.025)$ & -0.012 & $(0.017)$ \\
\hline$\Delta \mathrm{PP} t+2$ & -0.002 & $(0.008)$ & -0.003 & $(0.007)$ & -0.002 & $(0.008)$ & -0.003 & $(0.007)$ & -0.001 & $(0.008)$ & -0.001 & $(0.008)$ \\
\hline$\Delta \mathrm{PP} \mathrm{t}+1$ & -0.004 & $(0.010)$ & -0.006 & $(0.009)$ & -0.004 & $(0.011)$ & -0.006 & $(0.010)$ & -0.007 & $(0.010)$ & -0.009 & $(0.011)$ \\
\hline$\Delta \mathrm{PP}$ & 0.007 & $(0.011)$ & 0.004 & $(0.012)$ & 0.009 & $(0.012)$ & 0.006 & $(0.012)$ & 0.003 & $(0.011)$ & 0.003 & $(0.012)$ \\
\hline$\Delta \mathrm{PP}$ t- 1 & 0.016 & $(0.011)$ & 0.013 & $(0.012)$ & 0.018 & $(0.012)$ & 0.015 & $(0.012)$ & 0.014 & $(0.012)$ & 0.013 & $(0.014)$ \\
\hline$\Delta \mathrm{PP} \mathrm{t}-2$ & 0.007 & $(0.012)$ & 0.007 & $(0.012)$ & 0.007 & $(0.013)$ & 0.007 & $(0.012)$ & 0.000 & $(0.012)$ & -0.003 & $(0.013)$ \\
\hline$\Delta \mathrm{PP} \mathrm{t}-3$ & -0.001 & $(0.013)$ & 0.001 & $(0.015)$ & 0.000 & $(0.014)$ & 0.001 & $(0.015)$ & -0.005 & $(0.014)$ & -0.006 & $(0.015)$ \\
\hline$\Delta \mathrm{PP} \mathrm{t}-4$ & -0.004 & $(0.014)$ & -0.002 & $(0.016)$ & -0.006 & $(0.015)$ & -0.003 & $(0.016)$ & -0.006 & $(0.015)$ & -0.008 & $(0.014)$ \\
\hline$\Delta \mathrm{PP} \mathrm{t}-5$ & 0.005 & $(0.013)$ & 0.008 & $(0.016)$ & 0.004 & $(0.014)$ & 0.008 & $(0.017)$ & 0.002 & $(0.014)$ & 0.001 & $(0.014)$ \\
\hline PP Lag t-6 & 0.001 & $(0.016)$ & 0.011 & $(0.018)$ & 0.000 & $(0.017)$ & 0.010 & $(0.019)$ & -0.004 & $(0.016)$ & -0.004 & $(0.016)$ \\
\hline$\Delta \mathrm{IC} \mathrm{t}+2$ & 0.002 & $(0.009)$ & -0.001 & $(0.008)$ & 0.002 & (0.009) & -0.001 & $(0.009)$ & 0.004 & $(0.010)$ & 0.000 & $(0.010)$ \\
\hline$\Delta \mathrm{IC} \mathrm{t}+1$ & 0.002 & $(0.009)$ & -0.003 & $(0.008)$ & 0.003 & $(0.010)$ & -0.002 & $(0.008)$ & 0.001 & (0.009) & -0.004 & (0.009) \\
\hline$\Delta \mathrm{IC}$ & -0.003 & $(0.012)$ & -0.007 & $(0.011)$ & -0.002 & $(0.011)$ & -0.006 & $(0.011)$ & -0.003 & $(0.012)$ & -0.009 & $(0.012)$ \\
\hline$\Delta \mathrm{IC} \mathrm{t}-1$ & 0.004 & $(0.011)$ & -0.002 & $(0.011)$ & 0.004 & $(0.011)$ & -0.002 & $(0.011)$ & 0.004 & $(0.011)$ & -0.003 & $(0.011)$ \\
\hline$\Delta \mathrm{IC} \mathrm{t}-2$ & -0.004 & $(0.012)$ & -0.010 & $(0.012)$ & -0.003 & $(0.013)$ & -0.009 & $(0.013)$ & -0.002 & $(0.012)$ & -0.009 & $(0.012)$ \\
\hline$\Delta \mathrm{IC} \mathrm{t}-3$ & -0.002 & $(0.012)$ & -0.007 & $(0.014)$ & -0.003 & $(0.013)$ & -0.007 & $(0.015)$ & 0.003 & $(0.013)$ & -0.005 & $(0.012)$ \\
\hline$\Delta \mathrm{IC} \mathrm{t}-4$ & 0.001 & $(0.013)$ & -0.003 & $(0.016)$ & 0.000 & $(0.013)$ & -0.004 & $(0.017)$ & 0.003 & $(0.013)$ & -0.005 & $(0.012)$ \\
\hline$\Delta \mathrm{IC} \mathrm{t}-5$ & -0.009 & $(0.014)$ & -0.013 & $(0.016)$ & -0.008 & $(0.014)$ & -0.012 & $(0.017)$ & -0.005 & $(0.014)$ & -0.012 & $(0.013)$ \\
\hline IC Lag t-6 & -0.002 & $(0.014)$ & 0.000 & $(0.017)$ & -0.002 & $(0.014)$ & 0.001 & $(0.018)$ & 0.001 & $(0.015)$ & -0.005 & $(0.013)$ \\
\hline Obs. & 110 &, 881 & 11 & 881 & & 881 & & & & 881 & & 881 \\
\hline
\end{tabular}

Notes: Huber-White robust standard errors clustered on state reported in parentheses. TFP is the establishment-level residual from a regression of valueadded on four factors of production (production employment, non-production employment, machinery and structures capital) at the industry-year level. 
App. Table 7: Dynamic Effects of Employment-at-Will Doctrines on

ASM Log Labor Productivity, 1976-1999

\begin{tabular}{|c|c|c|c|c|c|c|c|c|c|c|c|c|}
\hline \multirow{3}{*}{$\begin{array}{c}\text { Legal } \\
\text { Exception } \\
\Delta \text { GF t+2 }\end{array}$} & \multicolumn{2}{|c|}{$\begin{array}{c}\text { State FE, } \\
\text { SIC2 FE, } \\
\text { YR FE }\end{array}$} & \multicolumn{2}{|c|}{$\begin{array}{l}\text { Col. } 1 \text { plus } \\
\text { State Trends }\end{array}$} & \multicolumn{2}{|c|}{$\begin{array}{l}\text { Col. } 1 \text { plus } \\
\text { SIC2-YR FE }\end{array}$} & \multicolumn{2}{|c|}{$\begin{array}{l}\text { Col. } 1 \text { plus } \\
\text { State Trends, } \\
\text { SIC2-YR FE }\end{array}$} & \multicolumn{2}{|c|}{$\begin{array}{c}\text { Plant FE, } \\
\text { YR FE }\end{array}$} & \multicolumn{2}{|c|}{$\begin{array}{c}\text { Col. } 5 \text { plus } \\
\text { State Trends, } \\
\text { SIC2-YR FE }\end{array}$} \\
\hline & \multicolumn{2}{|c|}{$(1)$} & \multicolumn{2}{|c|}{ (2) } & \multicolumn{2}{|c|}{ (3) } & \multicolumn{2}{|c|}{ (4) } & \multicolumn{2}{|c|}{$(5)$} & \multicolumn{2}{|c|}{ (6) } \\
\hline & -0.004 & $(0.029)$ & -0.013 & $(0.015)$ & 0.007 & $(0.022)$ & -0.007 & $(0.012)$ & -0.022 & $(0.030)$ & -0.016 & $(0.018)$ \\
\hline$\Delta \mathrm{GF} \mathrm{t}+1$ & -0.020 & $(0.028)$ & -0.029 & $(0.015)$ & -0.008 & $(0.022)$ & -0.022 & $(0.012)$ & -0.037 & $(0.029)$ & -0.031 & $(0.020)$ \\
\hline$\Delta \mathrm{GF}$ & -0.017 & $(0.040)$ & -0.033 & $(0.028)$ & -0.001 & $(0.029)$ & -0.020 & $(0.020)$ & -0.037 & $(0.041)$ & -0.027 & $(0.029)$ \\
\hline$\Delta \mathrm{GF}$ t-1 & -0.010 & $(0.037)$ & -0.031 & $(0.024)$ & 0.007 & $(0.027)$ & -0.017 & $(0.018)$ & -0.030 & $(0.038)$ & -0.021 & $(0.026)$ \\
\hline$\Delta \mathrm{GF}$ t -2 & 0.024 & $(0.027)$ & -0.012 & $(0.019)$ & 0.033 & $(0.023)$ & -0.002 & $(0.017)$ & 0.004 & $(0.028)$ & 0.009 & $(0.017)$ \\
\hline$\Delta \mathrm{GF}$ t-3 & 0.022 & $(0.028)$ & -0.024 & $(0.022)$ & 0.032 & $(0.023)$ & -0.010 & $(0.018)$ & 0.000 & $(0.030)$ & 0.004 & $(0.021)$ \\
\hline$\Delta \mathrm{GF} \mathrm{t-4}$ & 0.018 & $(0.029)$ & -0.038 & $(0.023)$ & 0.030 & $(0.024)$ & -0.019 & $(0.020)$ & -0.003 & $(0.031)$ & 0.003 & $(0.021)$ \\
\hline$\Delta \mathrm{GF}$ t -5 & 0.022 & $(0.027)$ & -0.042 & $(0.023)$ & 0.032 & $(0.022)$ & -0.023 & $(0.020)$ & 0.002 & $(0.027)$ & 0.007 & $(0.020)$ \\
\hline GF Lag t-6 & 0.068 & $(0.034)$ & -0.056 & $(0.029)$ & 0.074 & $(0.029)$ & -0.026 & $(0.022)$ & 0.044 & $(0.034)$ & 0.046 & $(0.021)$ \\
\hline$\Delta \mathrm{PP} \mathrm{t}+2$ & 0.018 & $(0.009)$ & 0.012 & $(0.005)$ & 0.014 & $(0.007)$ & 0.015 & $(0.004)$ & 0.017 & $(0.010)$ & 0.010 & $(0.007)$ \\
\hline$\Delta \mathrm{PP} \mathrm{t}+1$ & 0.017 & $(0.011)$ & 0.011 & $(0.008)$ & 0.013 & $(0.009)$ & 0.015 & $(0.007)$ & 0.016 & $(0.012)$ & 0.008 & $(0.009)$ \\
\hline$\Delta \mathrm{PP}$ & 0.017 & $(0.012)$ & 0.010 & $(0.009)$ & 0.010 & $(0.010)$ & 0.013 & $(0.009)$ & 0.017 & $(0.013)$ & 0.006 & $(0.010)$ \\
\hline$\Delta \mathrm{PP}$ t- 1 & 0.025 & $(0.013)$ & 0.015 & $(0.010)$ & 0.017 & $(0.010)$ & 0.020 & $(0.010)$ & 0.024 & $(0.014)$ & 0.011 & $(0.011)$ \\
\hline$\Delta \mathrm{PP} \mathrm{t}-2$ & 0.016 & $(0.014)$ & 0.012 & $(0.010)$ & 0.010 & $(0.012)$ & 0.020 & $(0.010)$ & 0.016 & $(0.014)$ & 0.006 & $(0.012)$ \\
\hline$\Delta \mathrm{PP} \mathrm{t}-3$ & 0.019 & $(0.013)$ & 0.015 & $(0.009)$ & 0.014 & $(0.012)$ & 0.023 & $(0.009)$ & 0.020 & $(0.014)$ & 0.010 & $(0.012)$ \\
\hline$\Delta \mathrm{PP} \mathrm{t}-4$ & 0.017 & $(0.014)$ & 0.013 & $(0.009)$ & 0.010 & $(0.012)$ & 0.021 & (0.009) & 0.017 & $(0.015)$ & 0.006 & $(0.013)$ \\
\hline$\Delta \mathrm{PP} \mathrm{t}-5$ & 0.010 & $(0.014)$ & 0.009 & $(0.010)$ & 0.004 & $(0.013)$ & 0.017 & $(0.009)$ & 0.011 & $(0.016)$ & 0.000 & $(0.013)$ \\
\hline PP Lag t-6 & -0.007 & $(0.019)$ & 0.006 & $(0.010)$ & -0.011 & $(0.016)$ & 0.015 & $(0.010)$ & -0.007 & $(0.021)$ & -0.012 & $(0.016)$ \\
\hline$\Delta \mathrm{IC} \mathrm{t}+2$ & -0.006 & $(0.009)$ & -0.003 & $(0.005)$ & -0.007 & $(0.007)$ & -0.002 & $(0.005)$ & -0.005 & (0.009) & -0.006 & $(0.007)$ \\
\hline$\Delta \mathrm{IC} \mathrm{t}+1$ & -0.005 & $(0.011)$ & -0.001 & $(0.007)$ & -0.007 & (0.009) & 0.000 & $(0.007)$ & -0.006 & $(0.012)$ & -0.007 & $(0.009)$ \\
\hline$\Delta \mathrm{IC}$ & -0.007 & $(0.013)$ & -0.003 & $(0.007)$ & -0.007 & $(0.011)$ & 0.001 & $(0.009)$ & -0.009 & $(0.014)$ & -0.007 & $(0.011)$ \\
\hline$\Delta \mathrm{IC} \mathrm{t}-1$ & -0.002 & $(0.013)$ & -0.001 & $(0.008)$ & -0.003 & $(0.012)$ & 0.002 & $(0.010)$ & -0.005 & $(0.014)$ & -0.005 & $(0.012)$ \\
\hline$\Delta \mathrm{IC} \mathrm{t}-2$ & 0.003 & $(0.014)$ & 0.004 & $(0.010)$ & 0.001 & $(0.012)$ & 0.005 & $(0.011)$ & 0.000 & $(0.015)$ & -0.002 & $(0.012)$ \\
\hline$\Delta \mathrm{IC} \mathrm{t}-3$ & 0.004 & $(0.015)$ & 0.004 & $(0.012)$ & 0.003 & $(0.014)$ & 0.006 & $(0.013)$ & 0.001 & $(0.016)$ & -0.001 & $(0.013)$ \\
\hline$\Delta \mathrm{IC} \mathrm{t}-4$ & 0.000 & $(0.016)$ & 0.001 & $(0.011)$ & 0.000 & $(0.014)$ & 0.004 & $(0.012)$ & -0.005 & $(0.016)$ & -0.007 & $(0.013)$ \\
\hline$\Delta \mathrm{IC} \mathrm{t}-5$ & 0.001 & $(0.017)$ & 0.002 & $(0.013)$ & 0.000 & $(0.015)$ & 0.004 & $(0.014)$ & -0.003 & $(0.017)$ & -0.007 & $(0.014)$ \\
\hline IC Lag t-6 & 0.002 & $(0.019)$ & 0.008 & $(0.013)$ & 0.003 & $(0.018)$ & 0.010 & $(0.016)$ & 0.000 & $(0.021)$ & -0.003 & $(0.017)$ \\
\hline Obs. & 135 & 972 & 135 & 972 & & & & 972 & 13 & 972 & & 972 \\
\hline
\end{tabular}

Notes: Huber-White robust standard errors clustered on state reported in parentheses. 